International Business Management 13 (3): 101-118, 2019

ISSN: $1993-5250$

(C) Medwell Journals, 2019

\title{
Value Relevance of Financial Performance Measures under IFRS: An Analysis of Eurpean Listed Companies
}

\author{
Fabio Rizzato, Donatella Busso and Alain Devalle \\ School of Management and Economics, University of Turin, Italy
}

\begin{abstract}
The aim of this research is to analyse the value relevance of the most common financial performance measures (Sales, EBITDA, EBIT, EBT, net income and total comprehensive income) using the value relevance methodology. The general regression model was applied according to two different approaches, each of which used with different variations in order to verify what financial performance measures can affect stock market capitalisation (and how they behave) according to the econometric model used. Specifically with the first approach we analysed data using an OLS Model with both pooled and panel datasets. In the second approach, we created models for the dataset to obtain a dynamic panel which we analysed using both the OLS and the GMM regression models. The sample consists of listed companies on the main European stock market indices (France, Germany, Italy, Spain, UK) for the period 2008-2013, totalling 175 groups analysed and 1.225 overall observations processed for each year (7.350 items overall). Results show that net income is the most value relevant financial performance measure, irrespective of the econometric model used. The issue is extremely topical, considering the IASB debate about introducing the EBIT as a mandatory sub-total in the income statement in order to satisfy user's needs.
\end{abstract}

Key words: Financial, performance measure, value relevance, IFRS, net income, annual report

\section{INTRODUCTION}

The financial statements of companies whose securities are traded on financial markets are an important source of information for investors who despite not relying solely on economic and financial data for their investment decisions (buying/selling/holding shares, lending money, etc.) cannot ignore the financial performance indicators presented in consolidated and annual financial statements.

For the IASB (Conceptual framework, para. OB2), the objective of financial statements prepared for "general purposes" is specifically to provide financial information on the reporting entity that is useful to existing and potential investors, lenders and other creditors. These subjects use the information when deciding whether or not to transfer financial resources to the company in the form of equity and loans.

Meeting the information needs of investors is an increasingly important objective for the IASB. In December 2014, the board launched a new programme (Investors in Financial Reporting Programme) aimed at increasing dialogue with the buy-side community in order to ensure that the IFRS continue to meet their information needs, i.e., that information presented in financial statements continues to be useful. In order to be useful an information must be relevant. According to the
IASB (Conceptual framework, para. Q6), information is relevant when it can make a difference to the decisions taken by users of the financial statements. Since, 2010 following the planned convergence with the US standard setter, the FASB also introduced the same definition for relevance (FASB, Concepts Statement No. 8). All financial information must be relevant including information on the performance of the reporting entity shown in the income statement (Anonymous, 2010).

Both the IASB and the FASB require companies to disclose revenue, net income (profit or loss for the IASB, earnings for the FASB) and total comprehensive income in their financial statements, although, there are still some differences between the two sets of accounting standards (Anonymous, 2012, 2013).

However, analysing the financial performance of an entity does not mean examining only revenues, net income and comprehensive income but also evaluating the other subtotals presented by companies. In this sense, the IASB and the FASB agree that the presentation of subtotal results is a way of disclosing relevant information to the users of financial statements. Even the chairman of the IASB, Hans Hoogervorst, recently (2014) stated that a single item cannot on its own capture everything that a user needs to know about the performance of an entity. Neither the IASB nor the FASB provide specific guidance on what subtotals

Corresponding Author: Fabio Rizzato, Department of Busineess Administration, School of Management and Economics, University of Turin, 10134 Turin, Italy 
should be disclosed with both boards leaving the decision to the entities themselves. The lack of specific performance measures provided by the standard setters has led to a debate in both the academic and the professional spheres on how to define the best performance measures for investors such as revenue, EBITDA, EBIT, net income, total comprehensive income, etc.

The Institute of Chartered Accountants of Scotland (ICAS) and the European Financial Reporting Advisory Group (EFRAG) commissioned a research to investigate what information capital providers use where and how this information is obtained and what additional information capital providers would like to have. Among the other results, the research of Cascino et al. (2016) shows that "professional investors are strongly anchored on the income statement when making both valuation and stewardship decisions. They have strong reservations about the representational faithfulness of bottom line figures being negatively affected by managerial estimates and judgements triggered by re-valuations that relate to balance sheet line items. This leads to increased reliance on non-GAAP measures (such as EBITDA) which in turn raises concerns about a lack of standardisation and comparability and supports a call for the development of a standardised set of performance measures to suit differing objectives".

Recently, the IASB is facing the topic. Specifically, from June-October 2016, the board and staff attended more than 40 meetings with stakeholders in the "Primary Financial Statements" project (IASB staff paper 21D, Primary Financial Statements project, November 2016). The users of financial statements expressed support for a project to improve the structure and content of primary financial statements, beginning with the statement (s) of financial performance. According to the staff paper, users expressed reasonably consistent support for the requirement of additional subtotals in the statement (s) of financial performance, e.g., Earnings Before Interest and Tax (EBIT), operating profit and some management view of profit such as recurring operating profit. Meanwhile "except in a few cases, users broadly saw OCI as a black box or 'dumping ground' and did not analyse OCI items in detail".

Financial performance measures and their relevance are therefore, an extremely topical issue. The aim of this paper is precisely to ascertain whether there is a more relevant measure of financial performance in the consolidated financial statements prepared in accordance with IFRS by companies belonging to the main European stock market indices. To achieve this objective, we used the value relevance approach defined by Hellstrom (2006) as "the ability of financial statement information to capture or summarise information affecting the stock price". According to Ota (2003), the Price Regression Model (PRM) derives from Ohlson (1995) Linear Information Model (LIM).

In our research, the general regression model was applied in two different approaches, each of which used with different variations in order to verify what financial performance measures can affect stock market capitalisation (and how they behave), according to the econometric model used. Specifically, with the first approach we analysed the data using an OLS (Ordinary Least Square) Model using both pooled and panel datasets. With the second approach, we created models for the dataset to obtain a dynamic panel which we analysed using both the OLS and the GMM (Generalized Method of Moments) regression models.

In our models, the dependent variable is the natural logarithm of market capitalization taken 4 months after the closing of the financial period and the independent variables are the following performance measures (Revenue (Sales), Earning Before Interest, Taxes, Depreciation and Amortization (EBITDA), Earning Before Interest Taxes (EBIT), Income Before Taxation (EBT), Net Income (NI) and Total Comprehensive Income (TCI).

The sample consists of listed companies on the main European stock market indices (France, Germany, Italy, Spain, UK) for the period 2008-2013, totalling 175 groups analysed and 1.225 overall observations processed for each year (7.350 items overall). The performance measures used and stock market capitalization were downloaded from the Thomson Reuters database except for total comprehensive income which was calculated manually for the entire period considered.

The results differ according to the econometric model used. However, the only accounting performance measure among those analysed that can affect market performance, measured by stock market capitalization is net income. In fact this measure is value relevant, regardless of which econometric model is used.

The research is innovative because unlike other studies, it is conducted solely with reference to financial statements prepared according to IFRS (Barton et al., 2010) it involves a longer period of time ( 8 years against 4 years with Aliabadi et al., 2013) and it compares different econometric models with a significant impact on the results.

In this sense, our research contributes to the international debate on performance measures and can be used by standard setters and other bodies who superv ise the financial markets when defining the performance measures that companies must mandatorily or optionally present in their financial statements. 
Literature review and hypothesis: In recent years, the international debate on the most "significant" performance measures has been stoked, firstly by the mandatory introduction of IFRS for European listed companies and secondly by the research conducted by the IASB and the FASB on the conceptual framework.

The importance of financial statement measures can be analysed using different methodologies, however, the most widespread in international literature is value relevance (Kim, 2011). The value relevance methodology is based on the use of predictive models for the value market or share returns. In other words, the aim of value relevance is to determine the intensity of the relationship between a dependent variable (e.g., market capitalization) and several independent variables (e.g., performance measures such as net income, total comprehensive income, etc). Hence, studies using value relevance investigate the extent to which the dependent variable is "explained" by the independent variables.

The aim of these analyses is to test empirically the usefulness of the accounting information for investors when it comes to making decisions about the reporting entity. In this way, value relevance studies provide indications that standard setters (such as the IASB and the FASB) should take into consideration.

The literature has many definitions for value relevance reflecting different aspects and different study perspectives. According to Hellstrom (2006) value relevance is defined as "the ability of financial statement information to capture or summarise information that affects share values".

Much criticism has been laid against studies based on value relevance, since, it does not take account of the factors that may affect dependent variables such as market capitalization. Nevertheless, the numerous studies based on value relevance have also, demonstrated their utility because some external factors affecting the financial markets cannot be measured or can only be measured subjectively and hence, they cannot be standardized (like, for example, information asymmetry). Some researchs including Holthausen and Watts (2001) have made further criticism of this model. However, as suggested recently by Veith and Werner (2014), the criticism can be laid against the methodological choices (such as the chosen time frame or the model used to support the results) which at first glance appear to be only technical but in fact have an impact on the results. Therefore, despite the criticism, the value relevance approach is still current (Anonoymous, 2012).

In recent years, value relevance studies have focused on two aspects: the transition to IFRS (Sami and Zhou,
2004; Alali and Foote, 2012; Kim, 2013; Qu and Zhang, 2015; Sami, 2015; Sun and Sari, 2016) and total comprehensive income including comparisons between different countries (Devalle et al., 2010).

First of all, the transition to IFRS in Europe and in the rest of the world has led many researchs to conduct studies on the different value relevance of financial statements prepared in accordance with local GAAP and those prepared according to international accounting standards in European and non-European countries or the effects of voluntary or mandatory adoption of IFRS.

Second, the IFRS have led to the introduction in Europe of total comprehensive income, the performance alternative to net income, the adoption of which has been the subject of intense debate. Brouwer et al. (2014) present a review of such studies from the 1990's-2014 and conclude that at present, evidence for value relevance and the predictive ability of total comprehensive income and its components (OCI-other components of comprehensive income) is conflicting and non-definitive.

Yet, the results of these studies led Brouwer et al. (2014) to claim that OCI are generally less predictive of future results and cash flows. Consequently, they also have a lower value relevance in relation to the items listed in the income statement that is net income. As part of a study on the suitability of the new IFRS conceptual framework, the researchers also highlight the need to verify the value relevance of the different disaggregation methods used for net income, namely the various performance measures that can be presented within an entity's income statement.

Our research begins with the results of the analysis carried out by Brouwer et al. (2014) which show that the distinction between net income and total comprehensive income is not the only relevant distinction that can be made to faithfully represent the performance of an entity. The researchers highlight that the studies published to date have been conducted on financial statements prepared using standards other than IFRS or where IFRS compliant, over a period of time that was not very lengthy.

The aim of this research, on the other hand is to analyse the value relevance of the most common financial performance measures in addition to net income and total comprehensive income and thus, contribute to the existing literature through an empirical analysis over a wide time span conducted on the IFRS-based financial statements of groups listed in European markets using different econometric models that have a significant impact on the results of the research conducted.

The literature contains studies that have investigated the intermediate results of the income statement or the cost and revenue components of the income statement. 
Int. Business Manage., 13 (3): 101-118, 2019

Table 1: Results of research on the value relevance of performance measures

\begin{tabular}{|c|c|c|c|c|c|c|c|}
\hline $\begin{array}{l}\begin{array}{l}\text { Researchers } \\
\text { (year) }\end{array} \\
\end{array}$ & Sample & Country & $\begin{array}{l}\text { Reference } \\
\text { years }\end{array}$ & $\begin{array}{l}\text { Accounting } \\
\text { standards }\end{array}$ & $\begin{array}{l}\text { Econometric } \\
\text { model used }\end{array}$ & Variables tested & Conclusion \\
\hline $\begin{array}{l}\text { Ohlson and } \\
\text { Penman (1992) }\end{array}$ & -- & -- & $1970-1987$ & -- & Regression models & $\begin{array}{l}\text { Disaggregation of income statement } \\
\text { components: gross margin; Operating costs, } \\
\text { depreciation and amortization, taxes, } \\
\text { expenses and income, extraordinary } \\
\text { income and expenses, dividends }\end{array}$ & $\begin{array}{l}\text { Overshat intervals, the different income } \\
\text { statement items have different impacts } \\
\text { on valuations }\end{array}$ \\
\hline Fairfield et al. & $\begin{array}{l}33.334 \\
\text { observations } \\
\text { company/year }\end{array}$ & -- & $1973-1990$ & -- & Regression models & $\begin{array}{l}\text { Disaggregation of net income into income } \\
\text { from recurring items, income from } \\
\text { extraordinary items and non-recurring items }\end{array}$ & $\begin{array}{l}\text { Disaggregation ofnet incomeinto(1996) } \\
\text { intermediate income improves ROE } \\
\text { forecasts for over } 1 \text { year ahead Jennings }\end{array}$ \\
\hline $\begin{array}{l}\text { et al. } \\
(2001)\end{array}$ & $\begin{array}{l}3.431 \\
\text { observations } \\
\text { company/year }\end{array}$ & -- & $1993-1998$ & US GAAP & $\begin{array}{l}\text { Regression models } \\
\text { with fixed year effect } \\
\text { in pooled dataset format }\end{array}$ & $\begin{array}{l}\text { Eamings per share before and after } \\
\text { goodwill adjustments }\end{array}$ & $\begin{array}{l}\text { Income before goodwill adjustments } \\
\text { is a better explanation for the variation } \\
\text { in share prices compared to income } \\
\text { after goodwill adjustments }\end{array}$ \\
\hline $\begin{array}{l}\text { Ertimur et al. } \\
(2003)\end{array}$ & $\begin{array}{l}\text { More than } \\
100,000 \\
\text { observations }\end{array}$ & -- & $1996-2001$ & -- & $\begin{array}{l}\text { Regression models with } \\
\text { interaction variables in } \\
\text { pooled and panel dataset }\end{array}$ & Revenues, costs, net income & $\begin{array}{l}\text { Share prices are affected by } \\
\text { announcements about revenues, not } \\
\text { only by those about net income }\end{array}$ \\
\hline $\begin{array}{l}\text { Chen and } \\
\text { Wang (2004) }\end{array}$ & $\begin{array}{l}2202 \text { firm-year } \\
\text { observations }\end{array}$ & $\begin{array}{l}\text { Chinese } \\
\text { stock } \\
\text { market }\end{array}$ & $1997-2000$ & -- & formats & Operating income and below-the-line items & $\begin{array}{l}\text { Both operating income and below-the } \\
\text { line items are value relevant but price } \\
\text { earning multiples are significantly } \\
\text { larger for below-the-line items than } \\
\text { for operating income. Second, the } \\
\text { time-series properties of operating } \\
\text { income vs. below-the-line items are } \\
\text { bothconsistentwith and different from } \\
\text { the perceived difference }\end{array}$ \\
\hline $\begin{array}{l}\text { Jegadeesh and } \\
\text { Livnat (2006) }\end{array}$ & $\begin{array}{l}165.708 \\
\text { observations }\end{array}$ & $\begin{array}{l}\text { United } \\
\text { States }\end{array}$ & $\begin{array}{l}1987-2003 \\
\text { the Fama-Mac }\end{array}$ & eth procedures & $\begin{array}{l}\text { Regression models with } \\
\text { coefficients estimated using } \\
\text { only by those about net incom } \\
\text { Pooled and panel dataset }\end{array}$ & $\begin{array}{l}\text { Quarterly share price } \\
\text { announcements about revenues, not } \\
\text { me }\end{array}$ & $\begin{array}{l}\text { Share prices are affected by } \\
\text { comp any/quarter }\end{array}$ \\
\hline $\begin{array}{l}\text { Banker and } \\
\text { Chen (2006) }\end{array}$ & $\begin{array}{l}8.771 \text { companies } \\
\text { and } 39.367 \\
\text { observations } \\
\text { company/year }\end{array}$ & -- & $1988-2002$ & -- & $\begin{array}{l}\text { Random effect } \\
\text { regression models with } \\
\text { pooled and panel datasets }\end{array}$ & $\begin{array}{l}\mathrm{R} \& \mathrm{D} \text {, operating income, adjusted } \\
\text { non-operating income, operating cash flow, } \\
\text { cash flow from investments, cash } \\
\text { flow from loans }\end{array}$ & $\begin{array}{l}\text { Disaggregation of net income into } \\
\text { measures that reflect the variability } \\
\text { of costs against revenues improves } \\
\text { ROE forecasts for over } 1 \text { year } \\
\text { ahead }\end{array}$ \\
\hline $\begin{array}{l}\text { Chandra and } \\
\text { Ro (2008) }\end{array}$ & $\begin{array}{l}390738 \\
\text { observations }\end{array}$ & $\begin{array}{l}\text { Multi } \\
\text { country }\end{array}$ & $1973-2003$ & $\begin{array}{l}\text { Several } \\
\text { GAAP }\end{array}$ & $\begin{array}{l}\text { Regression models with } \\
\text { pooled dataset }\end{array}$ & Revenues & $\begin{array}{l}\text { The incremental value relevance of } \\
\text { revenue is pervasive and increases } \\
\text { over time }\end{array}$ \\
\hline Bartonet al. & $\begin{array}{l}26479 \\
\text { companies and } \\
206730 \text { observation } \\
\text { company/year }\end{array}$ & $\begin{array}{l}\text { Multi } \\
\text { country } \\
\text { ons }\end{array}$ & $1996-2005$ & $\begin{array}{l}\text { Several } \\
\text { GAAP }\end{array}$ & $\begin{array}{l}\text { Different regression } \\
\text { models including fixed } \\
\text { effect regression models } \\
\text { Panel dataset }\end{array}$ & $\begin{array}{l}\text { Cash flow, sales, EBITDA, operating } \\
\text { income, income before taxes, current } \\
\text { income, net income, total comprehensive } \\
\text { income }\end{array}$ & $\begin{array}{l}\text { Thevahuerelevance(2010)(2010)(2001) } \\
\text { of "above the line" income statement } \\
\text { measures is greater than the revenues } \\
\text { and comprehensive income }\end{array}$ \\
\hline $\begin{array}{l}\text { Aliabadiet al. } \\
\text { (2013) }\end{array}$ & $\begin{array}{l}302 \text { companies } \\
\text { and } 1208 \\
\text { observations comp }\end{array}$ & $\begin{array}{l}\text { Multi } \\
\text { country } \\
\text { pany/year }\end{array}$ & $2006-2009$ & IFRS & $\begin{array}{l}\text { Fixed effect regression } \\
\text { models and panel datasets }\end{array}$ & ROE, change in sales, net income, ROA & $\begin{array}{l}\mathrm{ROA} \text { is the most value relevant } \\
\text { performance measure }\end{array}$ \\
\hline
\end{tabular}

However, unlike the data used in this research, the sample is not based on IFRS data alone or on an analysis of the European-only market. There now follows a review of the main studies concerning the value relevance of various performance measures other than net income or comprehensive income alone (Table 1).

Ohlson and Penman (1992) evaluated empirically how disaggregated accounting data were an explanatory variable for returns. The results of their analysis show that over short intervals, the various income statement items (such as depreciation and taxes) affect valuations differently.

Fair-Field et al. (1996) show that the disaggregation of net income into operating earnings, non-operating earnings, taxes, special items, extraordinary items and discontinued operations improves 1 year ahead return-on-equity forecasts.

Jennings et al. (2001) found that income before goodwill adjustments is a better explanation for the variation in share prices compared to income after goodwill adjustments. Ertimur et al. (2003) and Jegadeesh and Livnat (2006) found that share prices are affected by announcements about revenues and not only by statements about net income. Chen and Wang (2004) report empirical results in two areas. First, they find that both operating income and below-the-line items are value relevant but price-earning multiples are significantly larger for below-the-line items than for operating income which is contradictory to the perceived difference in persistence between these two types of earnings. Second, they demonstrate that the time-series properties of operating income vs. below-the-line items are both consistent with and different from the perceived difference. While operating income is more persistent and has significantly larger power in predicting future earnings than below-theline items they find that below-the-line items in China also, persist into the future and are of predictive values. Combining the first two findings, they conclude that the pricing of operating income and below-the-line items in the Chinese stock market is rational to the degree that persistent earnings, no matter recurring or below-the-line items are reflected in stock prices. Banker and Chen (2006) reach similar conclusions when considering the disaggregation of the net income into components that reflect the variability 
of costs with sales revenues. Chandra and Ro (2008) found that the incremental value relevance of revenue is pervasive and increases over time. Barton et al. (2010) conducted a study on the value relevance of eight performance measures (sales, EBITDA, operating income, income before tax, income before extraordinary items and discontinued operations, net income and comprehensive income). Their investigation was carried out on a sample of 26,479 companies over the period 1996-2005 for a total of 206,730 company-years across different countries. The results of their investigation show that no single performance measure clearly dominates the others but that measures that are "above the line" in the income statement (EBITDA and EBIT) are more value relevant than revenues (upper part of the income statement) or comprehensive income (lower part of the income statement).

Aliabadi et al. (2013) extended the study by Barton et al. (2010) using more recent data and conducting their investigation according to business sector. Specifically, the performance measures examined were ROE (Return on Equity), ROA (Return on Assets), operating income, net income and income before extraordinary items (the last three normalized against revenues). Their study confirms a significant association between market performance and accounting data, identifying ROA as the most value relevant performance measure. According to the researchers this is due to the fact that ROA contains both revenues and costs from the income statement and assets from the balance sheet.

The above studies seem to confirm the relevance of financial performance measures in addition to net income and comprehensive income, even if the results are not consistent. In addition, IAS 1 does not require the disclosure of subtotal in the income statement, leaving the companies themselves to decide which income to disclose and in how much detail.

The importance of subtotals is also demonstrated by the increase that has taken place, since, the 1990's in "nonGAAP measures" (or "alternative performance measures" or "Pro forma earnings" or "Street earnings") disclosed in company reports. Numerous studies have been conducted on these measures on the reasons that drive companies to disclose these results and on their greater/lesser value relevance with respect to the data presented in the financial statements. The spread of this practice has generated concern among financial market regulators which over the years have issued directives and guidelines on how to disclose these measures and how they should be reconciled with the data presented in the financial statements. After issuing a position paper in May 2014 in June 2015 the
European Securities and Markets Authority (ESMA) issued a final report on "Guidelines on Alternative Performance Measures". In the discussion study (2013) on the conceptual framework, even the IASB states that some individuals who commented on the previous discussion paper consider the use of non-GAAP measures by companies to explain their income to be an indication that net income and total comprehensive income might not by itself be a useful measure of the performance of an entity (Anonymous, 2015).

Recently, the IASB has gone back to the issue: at the beginning of 2015, the primary financial statements project was launched with the aim of examining the purpose, structure and content of primary financial statements. Among the various topics analysed, the board identified the following, the structure and content of the statement (s) of financial performance vary even among entities in the same industry, many entities present an operating profit subtotal that corresponds broadly to Earnings Before Interest and Tax (EBIT) but these subtotals are often calculated differently, many entities also, present an adjusted operating profit (e.g., operating profit before non-recurring items) but adjustments vary and lack transparency. During more than 40 meetings from June-October 2016 users expressed their support for improving financial statements by requiring additional sub-totals in the statement of financial performance. They thought the board should begin with the statement (s) of financial performance because these contain the least structure under current IFRS requirements and most alternative performance measures attempt to provide information that is based on these statements.

Cascino et al. (2016) proves that professional investors are strongly anchored on the income statement when making both valuation and stewardship decisions. Moreover, professional investors call for the development of a standardised set of performance measures to suit differing objectives.

The "Primary Financial Statements" project is currently under discussion but it seems highly probable that the board is going to respond positively to this call. In fact, the board has declared its intention to issue a discussion paper or an exposure draft by the end of the first semester 2018 and according to the current discussions (IASB, Staff Paper 21A, 2017), EBIT could become a mandatory and well-defined performance measure. According to discussions, the board does not want to introduce EBITDA as a mandatory subtotal, even if according to different studies is a very common used performance measure (Cascino et al., 2016) and also, a relevant one (Barton et al., 2010). In fact, according to the staff paper 21A (March, 2017) the staff of the IASB thinks that the 
board should not pursue requiring and defining EBITDA for the following reasons, the presentation of an EBITDA subtotal in the statement $(\mathrm{s})$ of financial performance is incompatible with the "function of expense" method (paragraph 103 of IAS 1 Presentation of Financial Statements ) because an EBITDA subtotal would disrupt the analysis of expenses, there are also some theoretical concerns about the concept of EBITDA. One of the main concerns is that EBITDA is often used as a measure of cash generation but it is in fact, a poor proxy for this. The board may, therefore, not want to encourage the use of this measure, particularly as cash flow information is already available in the statement of cash flows, during IASB's outreach, users told the staff that if a standardised EBIT subtotal is introduced they would be able to calculate EBITDA by simply adding back depreciation and amortisation themselves. On the basis of the literature examined, our hypothesis is the following:

- $\mathrm{H}_{1}$ : revenue, EBITDA, EBIT and net income are value relevant whereas total comprehensive income is not. We do not expect a clear relationship between the EBT and market capitalization

\section{MATERIALS AND METHODS}

Research design: In order to demonstrate our research hypothesis, we used a general linear regression model adopted by the main existing international practice (Barton et al., 2010; Aliabadi et al., 2013; Devalle et al., 2010; Veith and Werner, 2014):

Performance $_{i t}=\beta_{0}+\beta_{1}\left(\text { Performance measure }_{j}\right)_{i t}+\varepsilon_{i t}$

The general format of the model includes a market performance indicator as a dependent variable. In our research, we identified the Market Capitalization (MktCap) taken 4 months after the closing date of the financial statements and carried out in several previous studies (3/4 months) (Hellstrom, 2006; Frank, 2002; King and Langli, 1998; Meulen et al., 2007; Devalle and Magarini, 2012; Devalle et al., 2015).

As described in study 2 , revenue (sales), Net Income (NI) and Total Comprehensive Income (TCI) are the only performance measures defined by IAS 1. EBIT is going to become the fourth performance measure defined by IFRS, due to the IASB's "Primary Financial Statements" project. EBITDA is used by investors but is not always disclosed in income statements in particular when costs are presented by function. Earning Before Taxes (EBT) is not mandatory by IFRS, even if income taxes are presented.
Therefore, to ascertain the determinants of the market capitalization value, we chose these six financial performance measures: revenue (sales), Earning Before Interest Taxes Depreciation and Amortization (EBITDA), Earning Before Interest and Taxes (EBIT), Earning Before Taxes (EBT), Net Income (NI) and Total Comprehensive Income (TCI).

As described in study 2 , the different studies shown in Table 1 are also, characterized by the dataset models used and the different econometric model adopted. Some studies use pooled and panel based econometric models (Ertimur et al., 2003; Jegadeesh and Livnat, 2006; Banker and Chen, 2006). Other studies use panel datasets only (Barton et al., 2010; Aliabadi et al., 2013) and others pooled datasets only (Jennings et al., 2001; Chandra and Ro, 2008). Furthermore, some studies use regression models with a fixed-year effect to offset the bias effects of the time factor (Jennings et al., 2001). Lastly, some research uses fixed effects models (Barton et al., 2010; Aliabadi et al., 2013) while some use random effect models (Banker and Chen, 2006).

Since, the various econometric approaches could affect the results for our research we adopted several research models in order to ascertain whether (and how) the regression structure and associated premises of the model alter the significance and intensity of the most value relevant measures.

In particular, in our research, the general regression model was applied according to two different approaches, each of which used with different variations in order to verify what financial performance measures can affect stock market capitalisation (and how they behave) according to the econometric model used. Specifically with the first approach, we analysed data using an OLS Model with both pooled and panel datasets. In the second approach, we created models for the dataset to obtain a dynamic panel which we analysed using both the OLS and the GMM regression models.

OLS regression models: The first model used in our research is a multiple linear regression OLS for which the database is not in panel format. In other words, we did not consider the fact that several observations are measured at different points in time for each of the companies analysed. The model used is the following:

$$
\begin{gathered}
\operatorname{Ln}(\text { MktCap })_{\text {it }}=\beta_{0}+\beta_{1}(\operatorname{Ln}(\text { Sales }))_{\text {it }}+\beta_{2}(\text { EBITDA })_{\text {it }}+ \\
\beta_{3}(\text { EBIT })_{\text {it }}+\beta_{4}(\text { EBT })_{\text {it }}+\beta_{5}(\mathrm{NI})_{\text {it }}+\beta_{6}(\text { TCI })_{\text {it }}+\varepsilon_{\text {it }}
\end{gathered}
$$


Where:

\begin{tabular}{|c|c|}
\hline $\operatorname{Ln}(\mathrm{N}$ & $\begin{aligned}= & \text { Natural logarithm of the company's } \\
& \text { market capitalization " } \mathrm{i} \text { " at time " } \mathrm{t} \text { " }\end{aligned}$ \\
\hline $\operatorname{Ln}(\text { Sales })_{\text {it }}$ & $\begin{array}{l}=\text { Natural logarithm of company turnover } \\
\text { "i" at time "t" }\end{array}$ \\
\hline EBITDA $_{i t}$ & $=$ EBITDA "i" at time " $\mathrm{t} "$ \\
\hline $\mathrm{EBIT}_{\mathrm{it}}$ & $=$ EBIT "i" at time " $\mathrm{t}$ " \\
\hline $\mathrm{EBT}_{\text {it }}$ & $=\mathrm{EBT}$ " $\mathrm{i}$ " at time " $\mathrm{t}$ " \\
\hline $\mathrm{NI}_{\mathrm{it}}$ & $=$ Company's net income "i" at time " $\mathrm{t}$ " \\
\hline $\mathrm{TCI}_{\mathrm{it}}$ & $\begin{array}{l}=\text { Total comprehensive income "I" at time } \\
\text { "t" as disclosed by the groups in } \\
\text { consolidated statement of comprehensive } \\
\text { income }\end{array}$ \\
\hline
\end{tabular}

The second model used in our research is a Fixed Effects (FE) Model also known as, a Least Square Dummy Variable (LSDV). The equation is as follows:

$$
\begin{gathered}
\operatorname{Ln}(\text { MktCap })_{\text {it }}=\beta_{0}+\beta_{1}(\operatorname{Ln}(\text { Sales }))_{\text {it }}+\beta_{2}(\text { EBITDA })_{\text {it }}+ \\
\beta_{3}(\text { EBIT })_{\text {it }}+\beta_{4}(\text { EBT })_{\text {it }}+\beta_{5}(\text { NI })_{\text {it }}+\gamma_{i} u_{i}+\varepsilon_{i t}
\end{gathered}
$$

where, in addition to the independent variables described previously, $\mathrm{U}_{\mathrm{i}}$ is the entity fixed effect independent variable. The model developed is as follows:

$$
\begin{gathered}
\operatorname{Ln}(\text { MktCap })_{\text {it }}=\beta_{0}+\beta_{1}(\operatorname{Ln}(\text { Sales }))_{\text {it }}+\beta_{2}(\text { EBITDA })_{\text {it }}+ \\
\beta_{3}(\text { EBIT })_{\text {it }}+\beta_{4}(\text { EBT })_{\text {it }}+\beta_{5}(\mathrm{NI})_{\text {it }}+\beta_{6}(\text { TCI })_{\text {it }}+\gamma_{\mathrm{i}} \mathrm{Dl}_{\mathrm{i}}+\ldots,+ \\
\gamma(\mathrm{n}-1)_{1}+\varepsilon_{\mathrm{it}}
\end{gathered}
$$

where, $\mathrm{D} 1_{\mathrm{i}}=1$ if $\mathrm{I}=1$ and $\mathrm{D} 1_{\mathrm{i}}=0$ otherwise. A similar logic is used for the other entity dummy variables. For Eq.2, we used the data in panel format and we included the entity dummy variables in order to consider within the general regression model the independent variables omitted in the panel data, when these varied between entities but not in time (entity fixed effects). This means, for example, the sector of activity rather than the listing market. The entity fixed effects are $n-1$ dummy variables where $n$ is the number of companies analysed. The third model used in our research is a fixed effect model with the addition of time fixed effects. The equation is as follows:

$$
\begin{gathered}
\operatorname{Ln}(\text { MktCap })_{i t}=\beta_{0}+\beta_{1}(\operatorname{Ln}(\text { Sales }))_{i t}+\beta_{2}(\text { EBITDA })_{i t}+ \\
\left.\beta_{3}(\text { EBIT })_{i t}+\beta_{4}(\text { EBT })_{i t}+\beta_{5}(N)\right)_{i t}+\gamma_{i} u_{i}+\delta_{\mathrm{t}} \mathrm{S}_{\mathrm{i}}+\varepsilon_{\mathrm{it}}
\end{gathered}
$$

where, in addition to the independent variables described previously and the entity fixed effects $U_{i}$ (Model 2), we included the time fixed effects that enable us to check the model for variables that are constant between the entities but which may vary over time (e.g., financial crisis, European-level regulatory changes etc). The model developed is as follows:

$$
\begin{gathered}
\operatorname{Ln}(\text { MktCap })_{\text {it }}=\beta_{0}+\beta_{1}(\operatorname{Ln}(\text { Sales }))_{\text {it }}+\beta_{2}(\text { EBITDA })_{\text {it }}+ \\
\beta_{3}(\text { EBIT })_{\text {it }}+\beta_{4}(\mathrm{EBT})_{\text {it }}+\beta_{5}(\mathrm{NI})_{\mathrm{it}}+\beta_{6}(\mathrm{TCI})_{\mathrm{it}}+\gamma_{1} \mathrm{D} 1_{\mathrm{i}}+\ldots,+ \\
\gamma_{\mathrm{n}-\mathrm{l}} \mathrm{D}(\mathrm{n}-1)_{\mathrm{i}}+\delta_{1} \mathrm{D} 1_{\mathrm{t}}+, \ldots,+\delta_{\mathrm{T}-\mathrm{D}} \mathrm{D}(\mathrm{T}-1)_{\mathrm{t}}+\varepsilon_{\mathrm{it}}
\end{gathered}
$$

where, $\mathrm{D} 1_{\mathrm{t}}=1$ if $\mathrm{t}=1$ and $\mathrm{D} 1_{\mathrm{t}}=0$ otherwise. A similar logic is used for the other time dummies variables. The time fixed effects are $\mathrm{T}-1$ dummy variables where $\mathrm{T}$ is the number of years analysed.

OLS versus dynamic panel: The limitation of the entity (LSDV) and time fixed effect Model (3) is that market capitalization of year $\mathrm{n}$ could be influenced not only by the independent variables used but also by entity's market capitalization of the previous year.

Market capitalization could be strongly correlated with the respective delays. If this hypothesis were true, we could conclude that there is time dependence of the dependent variable and hence, persistence. This would imply that the standard errors in the Model (M4) could be not random, hence, violating one of the basic conditions of OLS Models. Indeed in the OLS Models, we take the mean standard error to be 0 and the variance to be constant:

$$
\mathrm{E}\left[\varepsilon_{\mathrm{i}}\right]=0 \mathrm{e} \mathrm{E}\left[\varepsilon_{\mathrm{i}}^{2}\right]=\delta^{2} \text { for }(\mathrm{i}=1, \cdots, \mathrm{n})
$$

To jointly estimate persistence and the ability of the explanatory variables to "explain" market capitalization, we included the lagged dependent variable $\left(\operatorname{LnMktCap}_{\mathrm{it}-1}\right)$ among the independent variables of the Model (M3). This way we obtained an autoregressive dynamic panel model. The general model is as follows:

$$
\begin{aligned}
& \operatorname{Ln}(\text { MktCap })_{i t}=\beta_{0}+\mu\left(\operatorname{Ln}(\text { MktCap })_{i t-1}\right)+ \\
& \beta_{1}\left(\text { Ln }(\text { Sales })_{\text {it }}\right)+\beta_{2}(\text { EBITDA })_{\text {it }}+\beta_{3}(\text { EBIT })_{\text {it }}+ \\
& \beta_{4}(\text { EBT })_{\text {it }}+\beta_{5}(\text { NI })_{\text {it }}+\beta_{6}(\text { TCI })_{\text {it }}+\gamma_{i} u_{i}+\delta_{t} S_{t}+\varepsilon_{i t}
\end{aligned}
$$

where in addition to the independent variables described previously, the entity fixed effects $U_{i}$ and the time fixed effects $S_{t}$, we included the lagged independent variable market capitalization ( $\left.\operatorname{Ln}(\mathrm{MktCap})_{\mathrm{it}-1}\right)$. Hence, this is a dynamic panel without the use of GMM panels. The main problem with the Model (M4) is that the error term $\varepsilon_{\mathrm{it}}$ is not uncorrelated with $\mathrm{L}_{\mathrm{n}}$ (MktCap) $)_{\mathrm{it}-1}$ in that $\mathrm{Ln}(\mathrm{MktCap})_{\text {it }}$ is not uncorrelated with $\varepsilon_{\mathrm{it}}$ This element 
contrasts with one of the main assumptions underlying the standard multiple regression that the variables $\mathrm{X}_{\mathrm{i}}$ must be manifestations of independent random variables from the error terms $\varepsilon_{\mathrm{it}}$. Inequation:

$$
\mathrm{E}\left[\varepsilon_{\mathrm{i}}, \mathrm{x}_{\mathrm{i}}\right]=0
$$

We must also, consider that our model might be affected by the presence of omitted variables and simultaneously by randomness where by the independent variable affects the dependent variable or vice versa.

To solve the issue of heteroscedasticity and autocorrelation of the standard errors, we made the following changes. Creation of the model's first difference:

$$
\begin{aligned}
& \left(\operatorname{Ln}(\text { MktCap })_{i t}-\operatorname{In}(\text { MktCap })_{i t-1}\right)=\left(\beta_{0}-\beta_{0}\right)+ \\
& \left(\mu \left(\text { Ln }(\text { MktCap })_{i t-1}-\mu\left(\operatorname{Ln}(\text { MktCap })_{i t-2}\right)+\right.\right. \\
& \left(\beta_{1} \operatorname{In}(\text { Sales })_{i t}-\beta_{1} \operatorname{In}(\text { Sales })_{i t-1}\right)+ \\
& \left(\beta_{2} \text { EBITDA }_{i t}-\beta_{2} \text { EBITDA }_{\mathrm{it}-1}\right)+ \\
& \left(\beta_{3} \mathrm{EBIT}_{\mathrm{it}}-\beta_{3} \mathrm{EBIT}_{\mathrm{it}-1}\right)+\left(\beta_{4} \mathrm{EBT}_{\mathrm{it}}-\beta_{4} \mathrm{EBT}_{\mathrm{it}-1}\right)+ \\
& \left(\beta_{5} \mathrm{Ni}_{\mathrm{it}}-\beta_{5} \mathrm{Ni}_{\mathrm{it}-1}\right)+\left(\beta_{6} \mathrm{TCI}_{\mathrm{it}}-\beta_{6} \mathrm{TCI}_{\mathrm{it}-1}\right)+ \\
& \left(\gamma_{\mathrm{i}} \mathrm{u}_{\mathrm{i}}-\gamma_{\mathrm{i}} \mathrm{u}_{\mathrm{i}}\right)+\left(\delta_{\mathrm{t}} \mathrm{S}_{\mathrm{t}}-\delta_{\mathrm{t}} \mathrm{S}_{\mathrm{t}-1}\right)+\left(\varepsilon_{\mathrm{it}}-\varepsilon_{\mathrm{it}-1}\right)
\end{aligned}
$$

Simplification and grouping of the coefficients:

$$
\begin{aligned}
& \left(\operatorname{Ln}(\text { MktCap })_{\text {it }}-\operatorname{In}\left(\text { MktCap }_{\text {it }-1}\right)=\mu\right. \\
& \left(\operatorname{Ln}(\text { MktCap })_{i t-1}-\operatorname{Ln}(\text { MktCap })_{i t-2}\right)+ \\
& \beta_{1}\left(\operatorname{In}(\text { Sales })_{\mathrm{it}}-\operatorname{In}(\text { Sales })_{\mathrm{it}-1}\right)+\beta_{2}\left(\text { EBITDA }_{\mathrm{it}}{ }^{-}\right. \\
& \text {EBITDA } \left._{\text {it }-1}\right)+\beta_{3}\left(\mathrm{EBIT}_{\mathrm{it}}-\mathrm{EBIT}_{\mathrm{it}-1}\right) \beta_{4}\left(\mathrm{EBT}_{\mathrm{it}}-\mathrm{EBT}_{\mathrm{it}-1}\right)+ \\
& \beta_{5}\left(\mathrm{Ni}_{\mathrm{it}}-\mathrm{Ni}_{\mathrm{it}-1}\right)+\beta_{6}\left(\mathrm{TCI}_{\mathrm{it}}-\mathrm{TCI}_{\mathrm{it}-1}\right)+\delta_{\mathrm{t}}\left(\mathrm{S}_{\mathrm{t}}-\mathrm{S}_{\mathrm{t}-1}\right)+\left(\varepsilon_{\mathrm{it}}-\varepsilon_{\mathrm{it}-1}\right)
\end{aligned}
$$

Simplification of the Model (M6) by introducing the operator "first difference" D:

$$
\begin{aligned}
& \text { D. }\left(\operatorname { L n } \left(\text { MktCap }_{\mathrm{it}_{\mathrm{t}}}=\mu\left(\text { D. }\left(\operatorname{Ln}\left(\text { MktCap }_{\mathrm{it}-1}\right)\right)+\right.\right.\right. \\
& \left.\beta_{1}\left(\text { D. }\left(\text { In }(\text { Sales })_{\mathrm{it}}\right)\right)+\beta_{2}(\text { D. (EBITDA })_{\mathrm{it}}\right)+ \\
& \beta_{3}\left(\mathrm{D} \cdot(\mathrm{EBIT})_{\mathrm{it}}\right)+\beta_{4}\left(\mathrm{D} \cdot(\mathrm{EBT})_{\mathrm{it}}\right)+\beta_{5}\left(\mathrm{D} \cdot(\mathrm{Ni})_{\mathrm{it}}\right)+ \\
& \beta_{6}\left(\mathrm{D} .(\mathrm{TCI})_{\mathrm{it}}\right)+\delta_{\mathrm{t}}\left(\mathrm{D} \cdot(\mathrm{S})_{\mathrm{t}}\right)+\mathrm{D} \cdot(\varepsilon)_{\mathrm{it}}
\end{aligned}
$$

As we can see from the Equation 9, the constant $\beta_{0}$ and the fixed effect $u_{i}$ no longer appear in the model because neither variable depends on time $t$. The advantage of the Model 7 lies in the fact that by taking the first differences we eliminated the potential bias of the unobservable variables $\mathrm{u}_{\mathrm{i}}$. Through the Model 7 we can find out how far the change in variables $\mathrm{X}_{\mathrm{i}}$ from the previous year can to impact on the change in market capitalization from the previous year.

However, the Model (7) presents endogenous variable issues: $\mathrm{D}\left(\mathrm{Ln}(\mathrm{MktCap})_{\mathrm{it}-1}\right)$ is correlated with $\mathrm{D}\left(\boldsymbol{\varepsilon}_{\mathrm{it}}\right)$ since, $\mathrm{Ln}(\mathrm{MktCap})_{\mathrm{it}-1}$ is correlated with $\varepsilon_{\mathrm{it}-1}$ (this is a direct consequence of the correlation between $\operatorname{Ln}(\mathrm{MktCap})_{\mathrm{it}-1}$ and $\varepsilon_{\mathrm{it}}$ ). This problem can be overcome by using the instrumental variables estimator 4 . The validity of the instrumental variables $Z_{\mathrm{i}}$ depends on the simultaneous fulfilment of two conditions which we tested:

- Significance of the instrument: $\operatorname{corr}\left(Z_{i}, X\right)_{1}=$ $\mathrm{E}\left[\mathrm{Z}_{\mathrm{i}} \mid \mathrm{X}_{\mathrm{i}}\right] \neq 0$

- Exclusion restriction or more generally, exogeneity: $\operatorname{corr}\left(Z_{\mathrm{i}}, \mathrm{e}_{\mathrm{i}}\right)=\mathrm{E}\left[\mathrm{e}_{\mathrm{i}} \mid \mathrm{Z}_{\mathrm{i}}\right]=0$

In our model we used two estimation techniques to estimate coefficients $\beta_{i}$ and identify instrumental variables IV. The first estimation technique dates back to 1991 (Arellano and Bond, 1991). It is based on using a difference GMM (Generalised Method of Moments). In our research, the difference GMM is based on the Mode1 7. To this we added as instruments (where $i$ is the number of nonstrict exogenous variables) the respective delays available in levels for differentiated variables that are not strictly exogenous.

With the difference GMM approach we get estimates that correct for endogeneity caused by the introduction of delays to our Model 7 (7-vs.A). The second estimation technique used in our research technique was proposed by Arellano and Bover (1995) and developed by Blundell and Bond (1998). It is known as system GMM.

This estimator again uses the generalised method of moments but differs from the previous model by adding to the equation in differences Eq. 7 the original equation in levels Eq. 4 creating a system. At this point, the model estimates delays in their respective first differences as instruments of the level equation for Model 4 whereas it estimates the respective delays available in levels as instruments of the not strictly exogenous variables in Model 7 (difference GMM Model). Thus, we get a system GMM like the one shown below (7-vs.B):

$$
\begin{aligned}
& \int \operatorname{Ln}(\text { MktCap })_{\mathrm{it}}=\beta_{0}+\mu\left(\operatorname{Ln}(\text { MktCap })_{\mathrm{it}-1}\right)+ \\
& \beta_{1}\left(\text { Ln }(\text { Sales })_{\mathrm{it}}\right) \beta_{2}(\text { EBITDA })_{\mathrm{it}}+\beta_{3}(\text { EBIT })_{\mathrm{it}}+ \\
& \beta_{4}(\mathrm{EBT})_{\mathrm{it}}+\beta_{5}(\mathrm{NI})_{\mathrm{it}}+\beta_{6}(\mathrm{TCI})_{\mathrm{it}}+\gamma_{\mathrm{i}} \mathrm{u}_{\mathrm{i}}+\delta_{\mathrm{t}} \mathrm{S}_{\mathrm{t}}+ \\
& \left\{\varepsilon _ { \mathrm { it } } \mathrm { D } \cdot \left(\operatorname{Ln}(\text { MktCap })_{\mathrm{it}}=\mu\left(\mathrm{D} \cdot\left(\operatorname{Ln}\left(\text { MktCap }_{\mathrm{it}-1}\right)\right)+\right.\right.\right. \\
& \beta_{1}\left(\text { D. }\left(\text { In }(\text { Sales })_{\text {it }}\right)\right)+\beta_{2}\left(\text { D. }(\text { EBITDA })_{\text {it }}\right)+ \\
& \begin{array}{l}
\beta_{3}\left(\mathrm{D} \cdot(\mathrm{EBIT})_{\mathrm{it}}\right)+\beta_{4}\left(\mathrm{D} \cdot(\mathrm{EBT})_{\mathrm{it}}\right)+\beta_{5}\left(\mathrm{D} \cdot(\mathrm{Ni})_{\mathrm{it}}\right)+ \\
\beta_{6}\left(\mathrm{D} \cdot(\mathrm{TCI})_{\mathrm{it}}\right)+\delta_{\mathrm{t}}\left(\mathrm{D} \cdot\left(\mathrm{S}_{\mathrm{t}}-\mathrm{S}_{\mathrm{t}-1}\right)\right)+\mathrm{D} \cdot\left(\varepsilon_{\mathrm{it}}\right)
\end{array}
\end{aligned}
$$


Int. Business Manage., 13 (3): 101-118, 2019

\section{Data}

Sample: The sample analysed includes the groups on the main European stock indices, namely:

- France, CAC 40

- Germany, DAX

- Italy, FTSE-MIB

- Spain, IBEX 35

- UK, FTSE 100

In total we analysed 245 groups that were listed on 31 December 2013. We excluded from the analysed sample financial groups (banks, insurance and financial services companies) as the main financial performance measures for these groups are different from those included in the financial statements of non-financial groups. We, therefore excluded 54 financial groups of which 4 listed in France, 7 in Spain, 6 in Germany, 24 in the UK and 13 in Italy. Of the remaining 191 non-financial groups we excluded 16 groups as they had values missing in the period under analysis (lack of specific values relevant to the investigation or absence of consolidated financial statements for at least 1 year in the period considered). In total, we analysed 175 listed non-financial groups in Europe with consolidated financial statements available for all the years considered in the analysis is shown in Table 2.

As can be seen in Table 2, we analysed more than $50 \%$ of the companies belonging to each stock market index and hence, the sample can be considered representative for each regulated market analysed.

As shown in the research design section for each group analysed we established 6 main measures of financial performance from the accounting information disclosed in the consolidated income statements and the consolidated statements of comprehensive income for the years included in the period (2008-2013). Thus, in total, we analysed 1,050 items for the independent variables and 175 items for the dependent variable for a total of 1,225 analysed items for each year (7,350 items overall).

Descriptive statistics: Table 3 shows the descriptive statistics of the variables used in our model. In Table 3, we present the descriptive statistics concerning the dependent variable "Market Capitalization" and the 6 independent variables common to all the models. We do not include entity dummy variables and time dummy variables, since, these are unobserved variables whose sole purpose is to consider any entity and time fixed effects in the model in order to safeguard the bias of the regression coefficients (Stock and Watson, 2003).
Table 2: Sample analysed

\begin{tabular}{lccc}
\hline & & \multicolumn{2}{c}{ Number of groups analysed } \\
Index & Number of groups (a) & No (b) & Percentage(b/a) \\
\hline CAC-40 & 40 & 36 & 90.0 \\
DAX & 30 & 24 & 80.0 \\
FTSE-MIB & 40 & 22 & 55.0 \\
IBEX-35 & 35 & 24 & 68.6 \\
FTSE-100 & 100 & 69 & 69.0 \\
Total & 245 & 175 & - \\
\hline
\end{tabular}

The first thing that, we notice is that there are no missing values in our sample because we used a balanced panel. All the variables were observed for each entity and for each time period.

The dependent variable "Market Capitalization" has a mean value of 17.83 billion Euros with a median of 8.971 billion Euros. Mean and median values have very different values between each other. Therefore, the frequency distribution deviates from its normal distribution. By construction, the market capitalization variable is always positive with a minimum value of 172.51 million Euros and a maximum value of 126.549 billion Euros. Given the characteristics of the dependent variable as in many similar studies, we chose the natural logarithm for market capitalization to contain the variability of the data ( $\mathrm{Ln}$ (MktCap)).

The first independent variable used in our model is sales. The behaviour of this variable is similar to the behaviour of market capitalization. The mean (equal to 24.43 billion Euros) and the median (10.57 billion Euros) values deviate greatly from each other. Together with the value of the standard deviation (49.43 billion Euros) this shows a strong dispersion of the value of sales from its normal distribution. In this case, too, we used the natural logarithm in order to contain the variability of the data $(\operatorname{Ln}($ Sales $))$.

The second independent variable in our model is EBITDA. The mean value in the sample is 3.92 billion Euros with a median of 1.50 billion Euros. The two values are less distant from each other, hence, the frequency distribution is closer to its normal distribution. Unlike Sales and market capitalization, EBITDA is negative with a minimum of -5.39 billion Euros and a maximum value of 59.12 billion Euros.

The third independent variable that we used is EBIT which differs from EBITDA because it considers depreciation and write-downs during the financial year. For this reason, EBIT has a mean (2.49 billion Euros) and a median (938.75 million Euros) that are lower than EBITDA. The minimum EBIT is -7.13 million Euros and the maximum value is 47.62 billion Euros. The marked difference between the EBIT and EBITDA 
Int. Business Manage., 13 (3): 101-118, 2019

Table 3: Descriptive statistics of variables used

\begin{tabular}{|c|c|c|c|c|c|c|c|c|}
\hline \multirow[b]{2}{*}{$\underline{\text { Variables }}$} & \multicolumn{2}{|l|}{ Dependent variable } & \multicolumn{6}{|c|}{ Independent variables } \\
\hline & MktCap & Sales & EBITDA & EBIT & EBT & NI & $\mathrm{TCI}$ & \\
\hline Description & $\begin{array}{l}\text { Market } \\
\text { capitalization }\end{array}$ & $\begin{array}{l}\text { Total revenues } \\
\text { from sales }\end{array}$ & $\begin{array}{l}\text { Earnings before } \\
\text { interest, taxes, } \\
\text { depreciation and } \\
\text { amortization }\end{array}$ & $\begin{array}{l}\text { Earnings before } \\
\text { interest and taxes }\end{array}$ & $\begin{array}{l}\text { Earnings before } \\
\text { taxes }\end{array}$ & Net income & $\begin{array}{l}\text { Total com } \\
\text { income }\end{array}$ & ensive \\
\hline Type of variable & e Numerical & Numerical & Numerical & Numerical & Numerical & Numerical & Numerica & \\
\hline Source of data & Thomson Reuters & Thomson Reuters & Thomson Reuters & Thomson Reuters & Thomson Reuters & Thomson Reuter & s Hand coll & ed \\
\hline Number of grou & & 175 & 175 & 175 & 175 & 175 & 175 & 175 \\
\hline Number of item & & 1050 & 1050 & 1050 & 1050 & 1050 & 1050 & 1050 \\
\hline Missing & 0 & 0 & 0 & 0 & 0 & 0 & 0 & \\
\hline Mean $\dagger$ & 17830.68 & 24429.02 & 3916.48 & 2490.56 & 2076.79 & 1351.71 & 1430.64 & \\
\hline Median $\dagger$ & 8971.73 & 10570.00 & 1496.27 & 938.75 & 746.77 & 526.00 & 463.29 & \\
\hline $\mathrm{SD}$ & 21832.11 & 49427.30 & 6523.62 & 4660.70 & 4471.30 & 2816.37 & 4125.43 & \\
\hline $\operatorname{Min} \dagger$ & 172.51 & 220.47 & -5385.64 & -7.130 & -8.672 & -9.289 & -20.370 & \\
\hline Max & 126549.50 & 829642.60 & 59124.77 & 47618.00 & 47095.10 & 26160.37 & 67055.35 & \\
\hline
\end{tabular}

†Values expressed in millions of Euros. The values not expressed in Euros by listed groups were converted into Euros based on the exchange rate on the date of publication of the consolidated financial statements for the independent variables and on the reference date for the market capitalization for the dependent variable

values demonstrates the importance of depreciation and write-downs in European listed groups. This also, corroborates our decision to include both these financial performance variables in the model.

The additional independent variables used in our model are "'Earnings Before Taxes" (EBT) and "Net Income" (NI). These differ because taxes are not considered in EBT. The mean EBT is 2.08 billion Euros and the median is 746.77 million Euros. By construction, the mean value of net income (1.35 billion Euros) and the median (526 million Euros) are lower than EBT. Both variables fluctuated less from the data than the mean value with a frequency distribution closer to normal distribution.

The last independent variable included in the model is "Total Comprehensive Income" (TCI) which shows statistically similar behaviour to EBT and NI. The mean value is 1.43 billion Euros and the median is 463.29 million Euros with a standard deviation of 4.13 billion Euros. The frequency distribution is close to normal distribution with a minimum value of -20.37 million Euros and a maximum value of 67.06 billion Euros.

\section{RESULTS AND DISCUSSION}

Graphical results: Before presenting our estimates on the financial measures that are able to significantly influence market capitalization it is useful to observe the behaviour in graph form of the dependent variable chart and the independent variables in the different years analysed.

Figure 1 shows the relationship between the dependent variable market capitalization and the different independent variables, regardless of the time factor. As we can see in a pooled dataset a positive relationship between the independent variables and the dependent variable seems to exist with the regression coefficients (graphically approximated by the regression line) that are similar to each other.

Figure 2 shows the graphs containing market capitalization in relation to the different independent variables for each year analysed. The aim is to show in graph form how the independent variables affect market capitalization differently depending on the year analysed. As can be seen through the use of more formal tests, this representation in graph form demonstrates the importance of using a panel model rather than the pooled model.

Results of the OLS regression model: The graphical analysis of the data in our database shows that depending on the model used (Pooled versus Panel date) very different results can be obtained for the regression coefficients, summarised in the slope of the regression lines.

On the basis of the findings from the graph analysis, we used three different configurations of the OLS Model for our research:

- OLS multiple linear regression model with pooled database

- $\quad$ Entity fixed effect model with panel datasets

- Entity and time fixed effect model with panel datasets

The results are shown in Table 4. As we can see from Table 4 the results obtained differ greatly depending on the configuration used to analyse the data. Specifically, they vary depending on whether a pooled model column 1 or a panel model columns 2 and 3 is used, they also, change depending on whether only entity fixed effects column 2 or entity and time fixed effects column 3 are considered. 
(a)

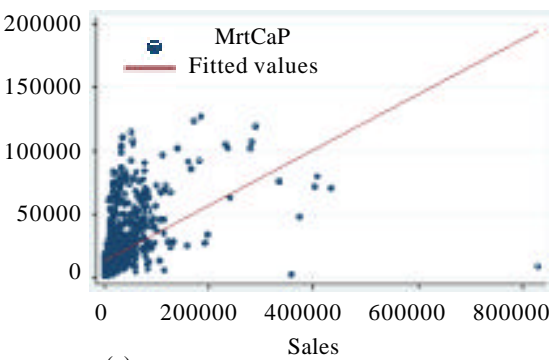

(c)
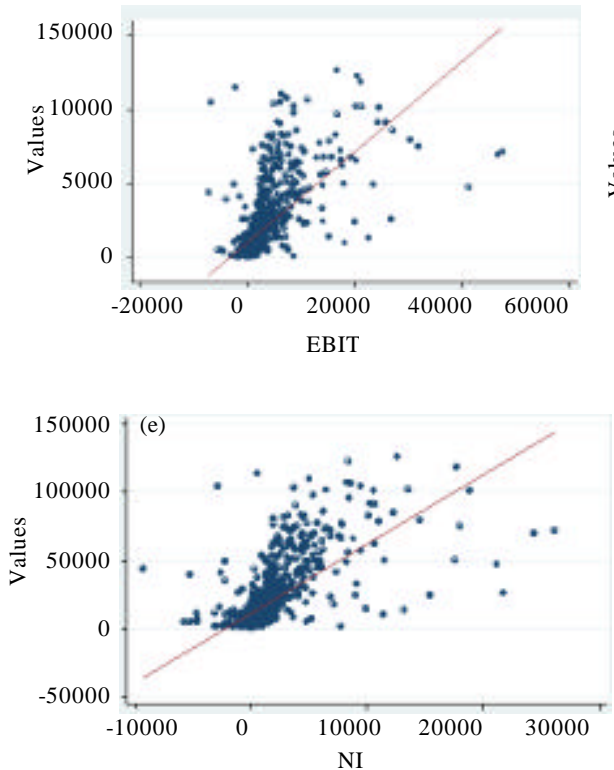

(b)

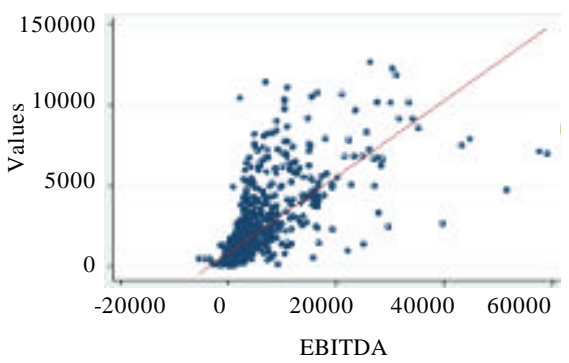

(d)
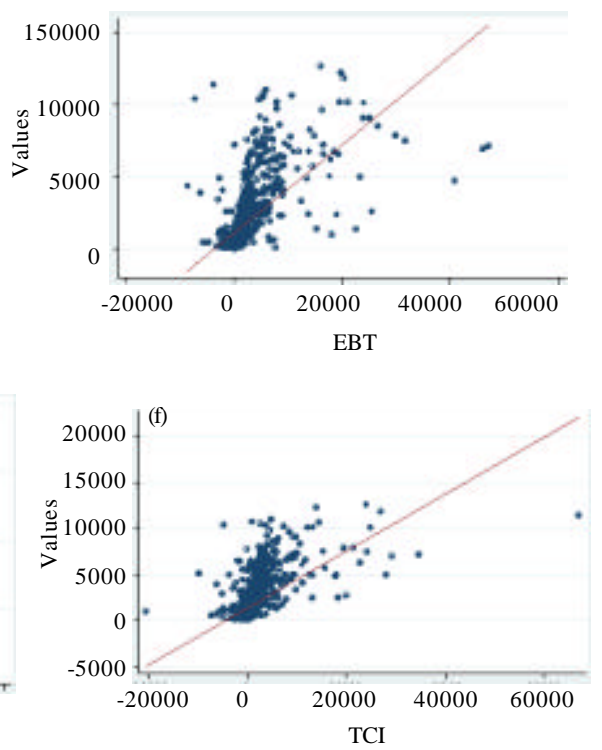

Fig. 1: (a-f) Market capitalization versus independent variables: scatter plot

Column 1 of Table 4 equation of Model 1 shows the results of the OLS regression without entity fixed effects and time fixed effects in pooled format. The $\mathrm{R}^{2}$ of the pooled model is 0.5614 , a value which is satisfactory also in light of the type of variables considered. The results in column (1) show how the natural logarithm of sales and net income can significantly and positively influence the natural logarithm of markets capitalization. Specifically, the natural logarithm of sales has a lower p-value less at 0.001 with a regression coefficient of 0.4465 . A $1 \%$ variation in sales corresponds to an increase in market capitalization of $0.4465 \%$. Net income also significantly $(\mathrm{p}-<0.001)$ and positively (coefficient of 0.00014701 ) influences market performance. A unit variation in net income increases market capitalization by $0.0147 \%$.

Total Comprehensive Income (TCI) positively influences market capitalization (coefficient of 0.00002624 ) but with a significance ( $p$-value $<0.01)$ lower than sales and above all, net income. The result for earnings before taxes is anomalous. According to our model, EBT significantly $(\mathrm{p}<0.01)$ and negatively $(\beta$ of -0.00017038$)$ affects market capitalization. A unit variation in EBT decreases market capitalization by $0.017038 \%$. This result might be caused by the use of the pooled model which is inappropriate dataset in a time-based dataset.

In the pooled model, EBITDA and EBIT do not seem to affect market capitalization. As they refer to a pooled Model (M1), the limitation of the results shown in column 1 is that more observations were recorded for each entity. This aspect means a potential correlation between the standard errors of the regression due to the observations not being independent of each other.

For this reason, we checked whether a fixed effect model was more reliable than a pooled model. We tested this using the Chow test, the null hypothesis $\left(\mathrm{H}_{0}\right)$ is that the coefficients of the entity dummy variables are equal to 0 and that a pooled regression is thus, the most suitable to represent the model: 
Int. Business Manage., 13 (3): 101-118, 2019

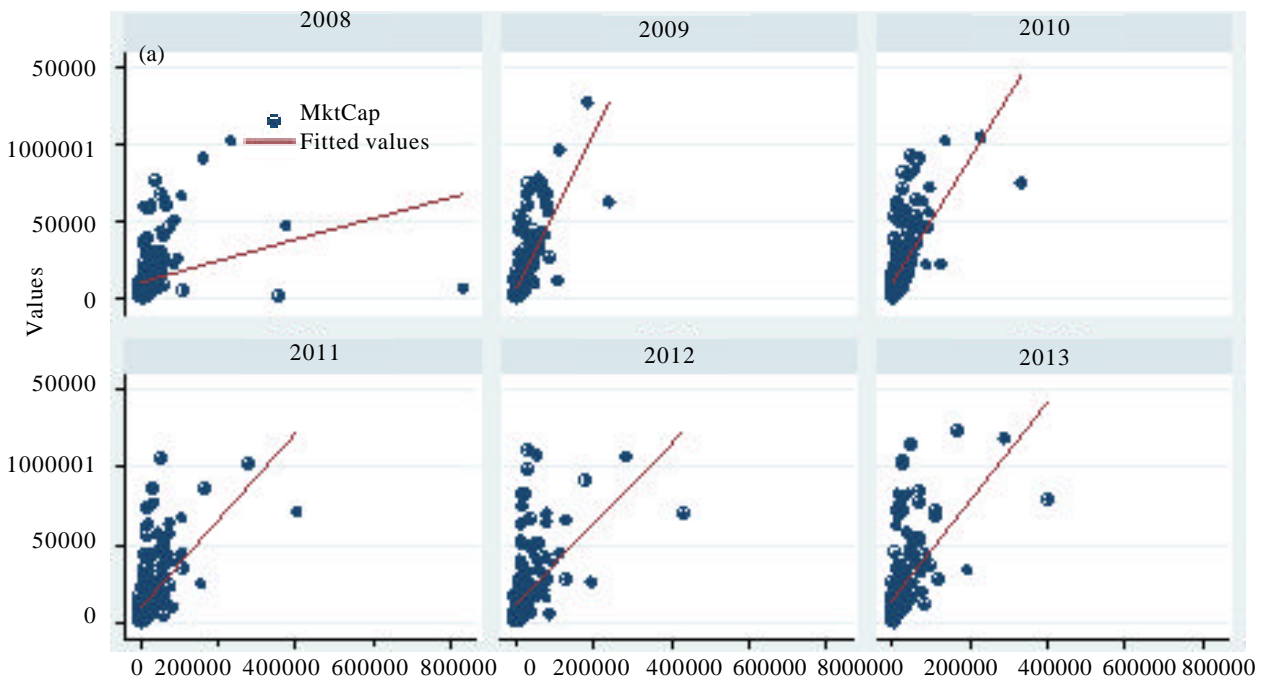

Sales
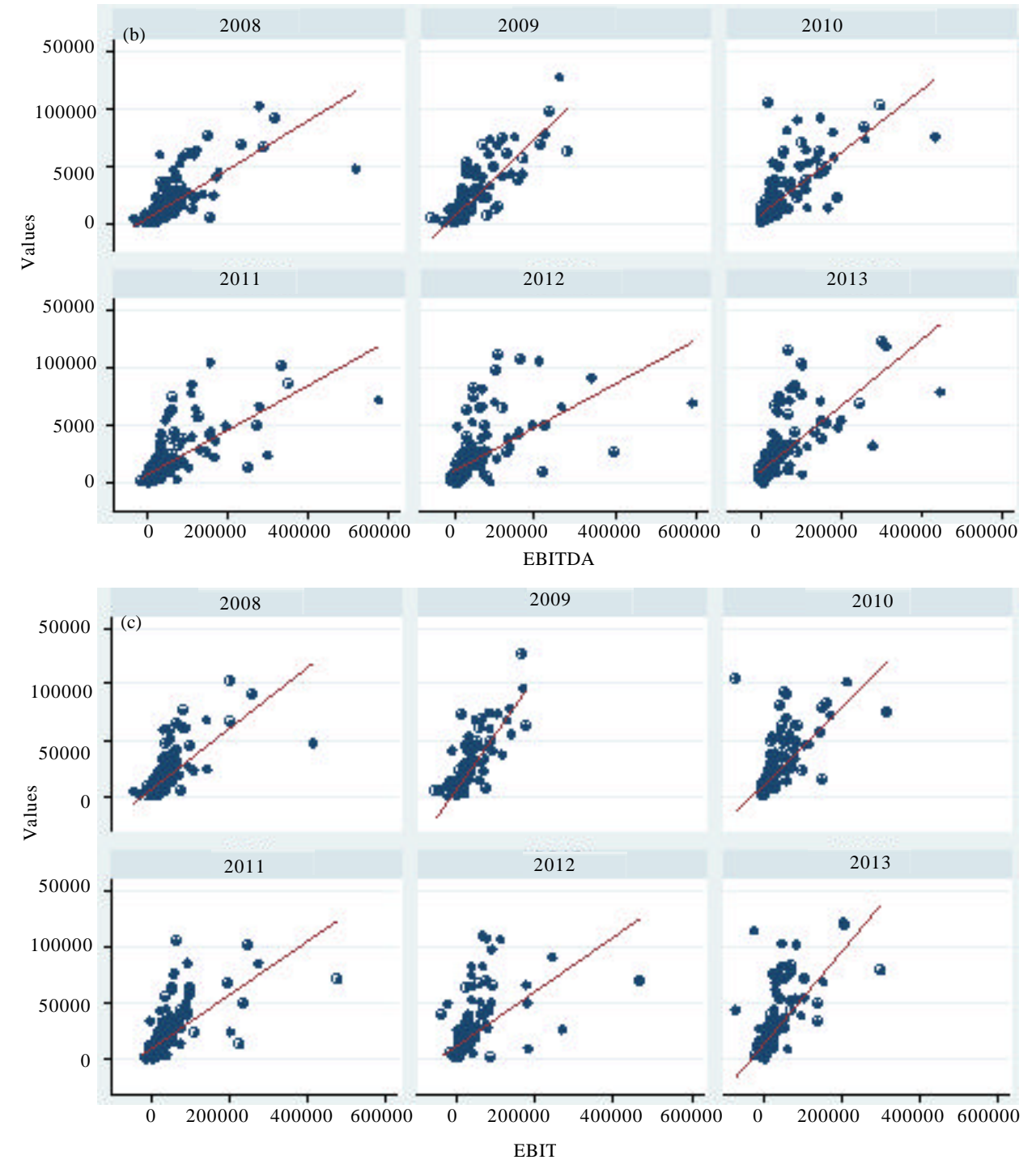

Fig. 2: Continue 
Int. Business Manage., 13 (3): 101-118, 2019
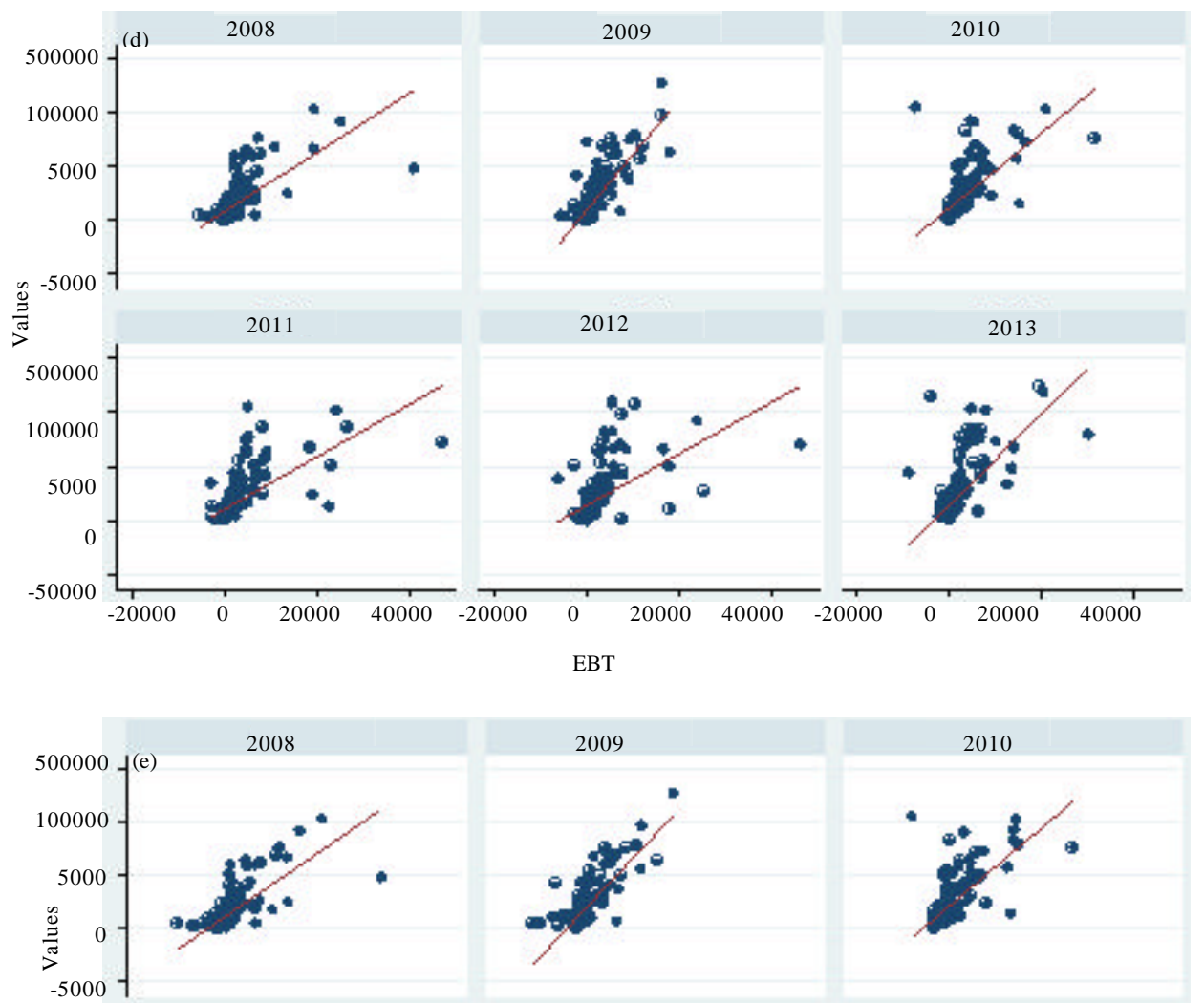

2011
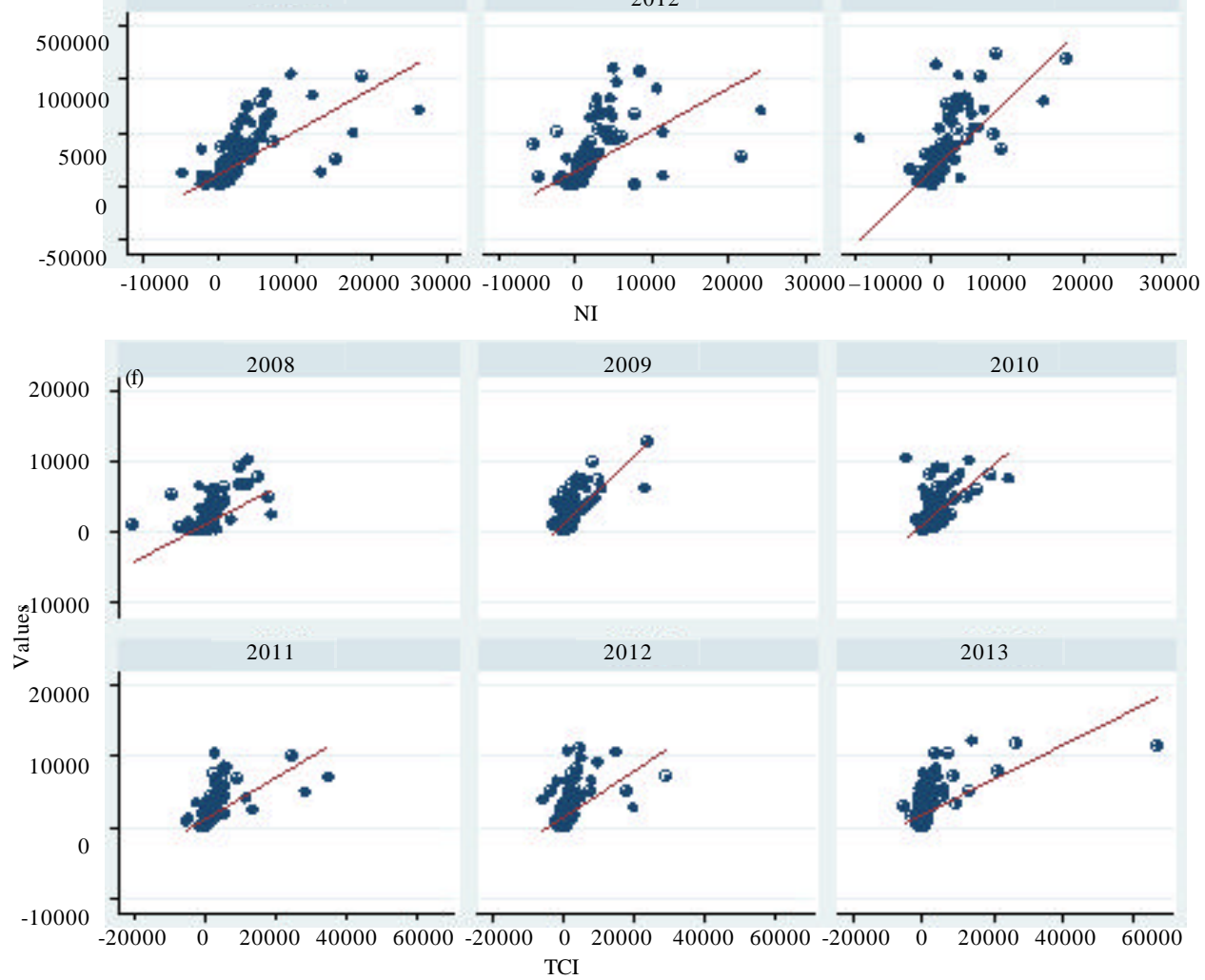

Fig. 2: (a-f) Market capitalization versus independent variables: panel data 
Int. Business Manage., 13 (3): 101-118, 2019

Table 4: Regression results

Dependent variable: natural logarithm of market capitalization

\begin{tabular}{|c|c|c|c|}
\hline \multirow[b]{3}{*}{ Regressor } & \multicolumn{3}{|l|}{ Models } \\
\hline & & & \\
\hline & $(1)$ & (2) & (3) \\
\hline Ln(Sales) & $0.44650223^{\text {*kekete }}$ & $0.1120208^{* * * k}$ & 0.02768655 \\
\hline EBITDA & 0.0000194 & $.00004776^{*}$ & -0.00003274 \\
\hline EBIT & 0.00009793 & $-0.00024652^{\text {*k+ketk }}$ & -0.00007123 \\
\hline EBT & $-0.00017038^{* * *}$ & $0.00017576^{*}$ & 0.00009437 \\
\hline NI & $0.00014701^{\text {****** }}$ & $0.00007352^{* * * *}$ & $0.000056^{* * *}$ \\
\hline TCI & $0.00002624^{\text {*k*k }}$ & $0.00001387^{\text {*k*k }}$ & $5.962 \mathrm{e}-06$ \\
\hline Years & $2008-2013$ & $2008-2013$ & $2008-2013$ \\
\hline Entity fixed effects & No & Yes & Yes \\
\hline $\begin{array}{l}\text { Entity and time } \\
\text { fixed effects }\end{array}$ & No & No & Yes \\
\hline F test & $222.51^{\text {*2*k** }}$ & $11.87^{* * * * * * *}$ & $47.70^{* * * * *}$ \\
\hline \multicolumn{4}{|c|}{ Chow test $\left(\right.$ all $\left.\mathrm{z}_{\mathrm{i}} \mathrm{i}=0\right) 19.11^{\text {**teks }}$} \\
\hline Hausman test & & $42.80^{\text {*2*3ket }}$ & \\
\hline $\mathrm{R}^{2}$ & 0.5614 & 0.07573802 & 0.9388 \\
\hline$\overline{\mathrm{R}^{2}}$ & 0.5588 & -0.11570865 & 0.9257 \\
\hline $\mathrm{N}$ & 1.050 & 1.050 & 1.050 \\
\hline No of groups & - & 175 & 175 \\
\hline
\end{tabular}

$$
\text { Chow }=\frac{\left(\operatorname{RSS}_{\mathrm{po}}-\mathrm{RSS}_{\mathrm{Fe}}\right) \mid \mathrm{K}}{\operatorname{RSS}_{\mathrm{Fe}} \mid(\mathrm{n}-2 \mathrm{k})}
$$

Where:

$\mathrm{RSS}_{\mathrm{po}}=$ Residual Sum of Square of pooled Model (M2) for the whole sample period

$\mathrm{RSS}_{\mathrm{Fe}}=$ Residual Sum of Square of fixed effect Model (M3) for the whole sample period

$\mathrm{N} \quad=$ Number of observations of equations

$\mathrm{K}=$ Number of estimate parameters

As we can see in Table 4, assuming $\mathrm{H}_{0}$ where the coefficients of the entity dummy variables are null, the value obtained from the Chow test (19.11) falls within the rejection region $(\mathrm{p}<0.01)$. We must, therefore, reject the null hypothesis, hence, the pooled model is suitable for analysis of the dataset.

Using a fixed effect model to replace the pooled model does not exclude the possibility of having to use a random effect model. For this reason, we performed the Hausman test before choosing the most appropriate model. The null hypothesis is that the coefficients estimated by the efficient random effects estimator $\left(\beta^{\mathrm{RE}}\right)$ are the same as those estimated by the fixed effects estimator $\left(\beta^{\mathrm{FE}}\right)$. Under the null hypothesis:

- $\quad \hat{\beta}^{\mathrm{FE}}$ is consistent: $\mathrm{P} \lim \hat{\beta}^{\mathrm{FE}}=\beta$

- $\quad \hat{\beta}^{\mathrm{RE}}$ is consistent: Plim $\hat{\beta}^{\mathrm{RE}}=\beta$

- $\hat{\beta}^{R E}$ is efficient

From condition 1 and 2 we get: $P \lim \left(\left(\hat{\beta}^{\mathrm{FE}}-\hat{\beta}^{\mathrm{RE}}\right)=0\right.$ and hence, the test can be based on the difference $\left(\hat{\beta}^{\mathrm{EE}}-\hat{\beta}^{\mathrm{RE}}\right)$. To summarise:

$$
\mathrm{H}_{0}: \operatorname{Var}\left(\beta^{\mathrm{FE}}\right)-\operatorname{Var}\left(\beta^{\mathrm{RE}}\right)=0
$$

If this difference is significantly different from 0 , the null hypothesis must be rejected in favour of the alternative Hypothesis $\left(\mathrm{H}_{1}\right)$ :

$$
\mathrm{H}_{1}: \operatorname{Var}\left(\beta^{\mathrm{FE}}\right)-\operatorname{Var}\left(\beta^{\mathrm{RE}}\right) \neq 0
$$

If the alternative hypothesis is used, the coefficients $\beta^{\mathrm{FE}}$ of the fixed effects model are consistent and efficient. Table 4 shows a Hausman test value of 42.80 which falls within the rejection region $(p<0.001)$. This result leads us to reject the null hypothesis (random effect) and conclude that the random effects model is not appropriate. Indeed we have no evidence of significant differences between the two estimators (coefficient) $\left(\beta^{\mathrm{RE}}\right.$ and $\beta^{\mathrm{FE}}$ ).

Column 2 (concerning the equation of Model 2 shows the results of the entity fixed effects model. As we can see, some coefficients change in terms of significance and in terms of relationship, a sign that the entity fixed effects have an impact on the change in data.

In the pooled model, the natural logarithm of sales decreases in significance $(p<0.01)$ and intensity $(\beta=$ 0.1120208 ) for market capitalization. With the introduction of entity fixed effects, a $1 \%$ change corresponds to a $0.1120 \%$ change in market capitalization.

Another interesting element that can be observed in Table 4 concerns EBITDA. In the entity fixed effects model, EBITDA significantly influence $(\mathrm{p}<0.05)$ and positively $(\beta$ $=0.00004776)$ affects market capitalization. $\mathrm{A}$ unit variation in EBITDA increases market capitalization by $0.00024652 \%$. The investor thus reacts positively to an increase in earnings before amortization and write-downs.

EBIT significantly $(\mathrm{p}<0.001)$ and negatively ( $\beta=-0.00024652)$ affects market capitalization. This result contrasts with the positive relationship of EBITDA with market capitalization. According to the regression coefficient of EBIT, a unit increase in EBIT corresponds to a $0.00024652 \%$ decrease in market capitalization. The positivity/negativity and intensity of the relationship may, however be influenced by omitted variables. EBT changes in intensity but above all, relationship. Table 4 shows that EBT significantly $(\mathrm{p}<0.05)$ and positively $(\beta=$ 0.00017576 ) affects market capitalization. In this case, too, the difference of the coefficient from the pooled model may be due to bias from variables omitted from the Model M1. Less important are the changes in Net Income $(\mathrm{NI})$ and Total Comprehensive Income (TCI) in terms of relevance and significance. In both models, NI and TCI significantly and positively influence market capitalization. This result shows that the dependency relationships between market 
capitalization and net income and between market capitalization and total comprehensive income were not affected by variables omitted from the model.

The limitation of the Model 2 is seen in a low value of $\mathrm{R}^{2}$, totalling 0.07573802 . This value along with the Hausman test result shows that the fixed effects Model 2 is to be preferred over the pooled Model 1. However, some important explanatory variables are still missing from the fixed effects Model 2 which could create bias in the regression coefficients due to omitted variables. For this reason, column 3 of Table 4 shows the results of the entity (LSDV) and time fixed effects model for the equation of Model 3. The first thing, we can see is that the $R^{2}$ passes from 0.07573802 (2) to 0.9388 thanks to the introduction of time effects to the model. This result shows how the time effects capture much of the variation in the data. $\overline{\mathrm{R}}^{2}$ is also close to $93 \%$ (0.9257).

Moreover, the results of the Model 3 completely change the significance of the explanatory variables. As we can see from Table 4, when the time variables are introduced to the fixed effects model, the only independent variable that can significantly $(p<0.01)$ and positively $(\beta$ $=0.00056)$ influence market capitalization is net income. A unit change in net income corresponds to a $0.000056 \%$ increase in market capitalization.

Therefore, we can briefly conclude that the significance and intensity of some independent variables shown in the fixed effects Model 2 are the result of omitted variable bias.

The results (very different from each other) of column 1 pooled model and column 3 entity and time fixed effects model are consistent with the hypothesis that the omitted fixed variables (entity and time) such as cultural and historical factors of the groups analysed business sector, location, listing stock market, economic and financial crisis and more generally, all those factors that are fixed in time for each entity (entity fixed effect) or which vary in time but not between entities (time effect) are important factors for determining the most value relevant accounting measures of market performance.

OLS versus dynamic panel-empirical results: Table 5, we correlated the dependent variable market capitalization in levels with the same variable in terms of delays. As we can see from the result, market capitalization is strongly correlated with the respective delays. We can, thus, conclude that there is time dependence of the dependent variable and hence, persistence. This result implies that the standard errors in the Model 4 are not random, hence, violating one of the basic conditions of OLS Models. The results of the dynamic panel are shown in Table 6.

The Model 3 presents the regression coefficient estimates of Eq. 3 using an OLS Model without considering the delayed effect of the dependent variable on the independent variables. These are the same results shown in column (3) of Table 4. As shown previously, net income is the only independent variable that can significantly $(p<0.009)$ and positively $(\beta=0.000056)$ affect market capitalization.

Unlike the Model 3 and 4 presents the coefficient estimates in the model in which market capitalization at time $\mathrm{t}$ is regressed on lagged market capitalization ( $\mathrm{t}-1)$ as in Eq. 4. This is still an OLS Model to which the lagged dependent variable has been introduced to the independent variables.

In the Model 4, all the independent variables used are able to significantly influence market capitalization, except total comprehensive income. However, these results in our research might be influenced by factors such as the heteroscedasticity and autocorrelation of the standard errors which bias significance and the determination of the regression parameters. In spite of this, we can see that even with the lagged dependent variable as the regressor, net income confirms its ability to explain significantly $(\mathrm{p}<0.028)$ and positively $(\beta=0.0000431)$ market capitalization. Despite the possible biasof the regression coefficients, the comparison of the results of Model 3 and 4 tells us that by introducing the lagged dependent variable among the independent variables, the significance and intensity of the relationship change considerably. On this basis it is demonstrated that the dynamic panel is the more powerful model for our evaluation. Indeed, the results set out in Table 6 show that in all models, except Model 3 , the persistence coefficient estimates are lower than one and are still able to significantly $(p<0.001)$ and positively influence market capitalization. These results lead us to conclude that in our research, we have to reject the hypothesis of perfect persistence $(\beta=1)$ in favour of the dynamic panel. In the Model (7-vs.A), we used a difference GMM. This model is based on the Eq. 7 to which we added the respective delays available in levels as instruments of the non-strictly exogenous variables $Z_{i}$.

In the Model (7-vs.A), we used the lagged dependent variable as the only endogenous variable. Consequently, we took all other independent variables in the Eq. 7 as strictly exogenous. We, therefore, only instrumented the persistence variable and used the delay in levels of the same variable as the instrument. 
Int. Business Manage., 13 (3): 101-118, 2019

Table 5: Autocorrelation of the dependent variables

\begin{tabular}{|c|c|c|c|c|c|c|}
\hline Variables & $\log _{\mathrm{MktCap}}$ & $\log \mathrm{MktCap}_{12}$ & Log MktCap 11 & $\log _{\mathrm{MktCa}} \mathrm{p}_{10}$ & Log MktCapo & Log MktCap \\
\hline $\log _{\mathrm{MktCap}}{ }_{12}$ & 1.0000 & - & - & - & - & - \\
\hline $\log \mathrm{MktCap}_{12}$ & 0.9775 & 1.0000 & - & - & - & - \\
\hline Log MktCap & 0.9478 & 0.9723 & 1.0000 & - & - & - \\
\hline${\log M k t C a p_{10}}$ & 0.9182 & 0.9199 & 0.9506 & 1.0000 & & \\
\hline Log MktCap, & 0.8871 & 0.8883 & 0.9161 & 0.9802 & 1.0000 & \\
\hline $\mathrm{Log}_{\mathrm{MktCap}}$ & 0.8434 & 0.8385 & 0.8661 & 0.9376 & 0.9697 & 1.0000 \\
\hline
\end{tabular}

Table 6: Lagged dependent variable and the difference dynamic panel models

\begin{tabular}{|c|c|c|c|c|c|c|c|c|c|c|c|}
\hline $\begin{array}{l}\text { Model (key, } \\
\text { assumption } \\
\text { estimator) }\end{array}$ & Persistence & Ln(Sales) & EBITDA & EBIT & EBT & NI & $\mathrm{TCI}$ & $\begin{array}{l}\text { Entity } \\
\text { fixed } \\
\text { effect }\end{array}$ & $\begin{array}{l}\text { Entity and } \\
\text { time } \\
\text { fixed effects }\end{array}$ & $\begin{array}{l}\text { Arellano- } \\
\text { bond test }\end{array}$ & $\begin{array}{l}\text { Hansen's } \\
\text { test }\end{array}$ \\
\hline $\begin{array}{l}\text { M3 No legged } \\
\text { dependent variable } \\
\text { (perfect persistence } \\
\beta=1, \text { OLS) }\end{array}$ & 1.00 & $\begin{array}{l}0.02768655 \\
(0.403)\end{array}$ & $\begin{array}{l}-0.00003274 \\
(0.064)\end{array}$ & $\begin{array}{l}-0.00007123 \\
(0.241)\end{array}$ & $\begin{array}{l}0.00009437 \\
(0.122)\end{array}$ & $\begin{array}{l}0.000056 \\
* *(0.009)\end{array}$ & $\begin{array}{l}0.000005962 \\
(0.150)\end{array}$ & Yes & Yes & & \\
\hline $\begin{array}{l}\text { M4 lagged } \\
\text { dependent } \\
\text { variable (OLS) }\end{array}$ & $\begin{array}{l}0.4141597 * * * * \\
(0.000)\end{array}$ & $\begin{array}{l}0.6475026 \text { ***** } \\
(0.000)\end{array}$ & $\begin{array}{l}-0.0000353 * \\
(0.022)\end{array}$ & $\begin{array}{l}-0.0003695 * * * \\
(0.000)\end{array}$ & $\begin{array}{l}0.000389 * * * * \\
(0.000)\end{array}$ & $\begin{array}{l}0.0000431 * \\
(0.028)\end{array}$ & $\begin{array}{l}0.00000030 \\
(0.066)\end{array}$ & Yes & Yes & & \\
\hline $\begin{array}{l}\text { M7-Vs.A different } \\
\text { dynamic panel } \\
\text { strictly exogenous } \\
\text { inputs (GMM) }\end{array}$ & $\begin{array}{l}0.433643 * * * * \\
(0.000)\end{array}$ & $\begin{array}{l}0.0881655 \\
(0.648)\end{array}$ & $\begin{array}{l}-0.0000252 \\
(0.276)\end{array}$ & $\begin{array}{l}-0.0001627 \\
(0.252)\end{array}$ & $\begin{array}{l}0.0001837 \\
(0.230)\end{array}$ & $\begin{array}{l}0.0000239 \\
(0.363)\end{array}$ & $\begin{array}{l}0.00000127 \\
(0.538)\end{array}$ & Yes & Yes & $\begin{array}{l}-2.93 \\
(0.003)\end{array}$ & $\begin{array}{l}115.38 \\
(0.023)\end{array}$ \\
\hline $\begin{array}{l}\text { M7-vs.B level and } \\
\text { difference system } \\
\text { GMM } \\
\text { predetermined inputs }\end{array}$ & $\begin{array}{l}0.91025 * * * * \\
(0.000)\end{array}$ & $\begin{array}{l}0.0237578 \\
(0.575)\end{array}$ & $\begin{array}{l}0.00000147 \\
(0.889)\end{array}$ & $\begin{array}{l}-0.0000518 \\
(0.115)\end{array}$ & $\begin{array}{l}0.0000354 \\
(0.275)\end{array}$ & $\begin{array}{l}0.0000302 * \\
(0.029)\end{array}$ & $\begin{array}{l}0.00000284 \\
(0.345)\end{array}$ & Yes & Yes & $\begin{array}{l}-4.56 \\
(0.000)\end{array}$ & $\begin{array}{l}139.07 \\
(0.125)\end{array}$ \\
\hline
\end{tabular}

In order to ascertain the absence of an autocorrelation between the standard errors and the exogeneity of the instrument used, we put the model (7-vs.A) to the Arellano-Bond and Hansen's test.

The null hypothesis in the Arellano-Bond test is that there is a first-order autocorrelation between the standard errors in the Model (7-vs.A). Table 6 shows the test value of -2.93 which falls with in the rejection region $(\mathrm{p}<0.003)$. We must, therefore, reject the null hypothesis and assume that there is no first-order autocorrelation between the standard errors.

The second test we conducted was Hansen's test to ascertain the exogeneity of the instruments. The null hypothesis in this test is that the instrument used in the model is exogenous. The value in Hansen's test is 115.38 which falls within the rejection region $(p<0.023)$. We must therefore reject the null hypothesis for the validity of the instrument used. The endogeneity of the instrument used means that the regression parameters may be biased and inefficient. This explains why in the Model (7-vs.A), no accounting performance variable is able to influence market capitalization Table 6.

To deal with the endogeneity of the instrumental variables, we adopted the Model (7-vs.B) which also uses the Generalised Method of Moments (GMM) but to the difference Eq. 7 it adds the original level Eq. 4, creating a system (hence, the term difference system GMM).

For the difference equation, we used the delays available in the respective levels as the instrumental variables for the level equation we used the delays in the respective first differences as the instrumental variables. Lastly, we took all independent variables as not strictly exogenous and hence, they were all instrumented. To ascertain the, validity of the instruments adopted in the Model (7-vs.B) we repeated the Arellano-Bond test and Hansen's test. Table 6 shows that the Arellano-Bond test gives a value $(-4.56)$ that falls within the rejection region $(p<0.000)$. We must therefore reject the null hypothesis and can assume that there is no first-order autocorrelation among the standard errors in the Model (7-vs.B), too.

With regard to the exogeneity of the instrumental variables, the result of Hansen's tests (139.07) leads us to accept the null hypothesis ( $p>0.05$ ) that is the hypothesis of the validity of the instrument. We can, therefore, conclude that the standard errors in the Model (7-Vs.B) are not autocorrelated and that the instrumental variables used are strictly exogenous. Thus, we can conclude that the regression coefficients (7-vs.B) are consistent, unbiased and efficient. The results of the Model (7-vs.B) shown in Table 6 tell us that net income is the only independent variable that can positively $(\beta=0.0000302)$ and significantly $(\mathrm{p}<0.029)$ affect market capitalization. A unit change in net income corresponds to a $0.0000302 \%$ increase in market capitalization.

We can, therefore, conclude that the only accounting performance measure, among those analysed that can affect market capitalization is net income as summarised in Table 7.

Table 7 shows how net income is a value relevant measure regardless of the econometric model used. If we analyse the results we can see that they can be divided into two groups: models without the lagged dependent variable and model with the addition of the lagged dependent variable. 
Int. Business Manage., 13 (3): 101-118, 2019

Table 7: Net income and different econometric approach

\begin{tabular}{|c|c|c|c|c|c|c|}
\hline \multirow[b]{2}{*}{ Variables } & \multicolumn{3}{|c|}{ No lagged dependent variables } & \multicolumn{3}{|c|}{ Lagged dependent variables } \\
\hline & $\begin{array}{l}\text { OLS Pooled } \\
\text { (M1) }\end{array}$ & $\begin{array}{l}\text { OLS fixed } \\
\text { effect (M2) }\end{array}$ & $\begin{array}{l}\text { OLS fixed effect-temporary } \\
\text { effect (M3) }\end{array}$ & $\begin{array}{l}\text { OLS lagged dependent } \\
\text { variable (M4) }\end{array}$ & $\begin{array}{l}\text { Difference GMM } \dagger \\
\text { (M7-vs.A) }\end{array}$ & $\begin{array}{c}\text { Differencesystem GMM } \\
\text { (M7-vs.B) }\end{array}$ \\
\hline Net income & 0.00014701 & 0.00007352 & 0.00005600 & 0.0000431 & 0.0000239 & 0.0000302 \\
\hline $\mathrm{P}$-value & 0.000 & 0.005 & 0.009 & 0.028 & 0.363 & 0.029 \\
\hline
\end{tabular}

Result not significant due to endogeneity of instrumental variables

If the models used do not consider the lagged dependent variable of market capitalization among the regressors, Table 7 shows how net income affect significantly $(0.000<\mathrm{p}<0.009)$ and positively market capitalization $(0.00005600<\beta<0.00014701)$ as well.

The result does not change if the lagged variable of market capitalization is considered among the independent variables. Indeed, Table 7 shows that net income significantly $(0.028<\mathrm{p}<0.029)$ and positively influences market capitalization $(0.0000302<\beta<0.0000431)$. In this second case, we can also see that the significance and intensity of the relationship has a narrower fluctuation range than in the absence of the lagged dependent variable. This is an even clearer sign of the ability of net income to explain the change in a company's market capitalization. This is also borne out by the fact that the dependency relationship does not change whether it is an OLS Model or a GMM Model used.

Consistent with $\mathrm{H}_{1}$ and using the level and difference system GMM, total comprehensive income is not value relevant whereas net income is value relevant. The hypothesis that revenue, EBITDA and EBIT are value relevant is rejected.

\section{CONCLUSION}

Financial performance measures and their relevance are an extremely topical issue for both practitioners and academics. The literature contains studies that have investigated the intermediate results of the income statement or the cost and revenue components of the income statement. However, results are not consistent and these studies are based on financial statements prepared using different accounting models and different econometric models.

The aim of this study is precisely to ascertain whether there is a more relevant measure of financial performance in the consolidated financial statements prepared in accordance with IFRS by companies belonging to the main European stock market indices. In our research, the general regression model was applied in two different approaches, each of which used with different variations in order to verify what financial performance measures can affect stock market capitalisation (and how they behave), according to the econometric model used.
Results show that the only value relevant performance measure is net income, irrespective of the model used. Our research contributes to the debate by providing an indepth analysis on the most value relevant financial performance measures (revenue, EBITDA, EBIT, EBT, net income and total comprehensive income). Our research is innovative because unlike other studies it is conducted solely with reference to financial statements prepared according to IFRS (175 European listed companies), it involves a longer period of time ( 8 years) and it compares different econometric models with a significant impact on the results.

Next step will be to analyse why the net income is the only value relevant financial performance measure. IASB, practitioners and academics must deal with this topic.

\section{REFERENCES}

Alali, F.A. and P.S. Foote, 2012. The value relevance of international financial reporting standards: Empirical evidence in an emerging market. Intl. J. Accounting, 47: $85-108$.

Aliabadi, S., A. Dorestani and N. Balsara, 2013. The most value relevant accounting performance measure by industry. J. Accounting Finance, 13: 22-34.

Anonymous, 2010. Conceptual framework statement of financial accounting concepts. Financial Accounting Standards Board, Norwalk, Connecticut, USA.

Anonymous, 2012. Conceptual framework. International Accounting Standards Board, London, UK.

Anonymous, 2013. Discussion paper: A review of the conceptual framework for financial reporting. International Accounting Standards Board, London, UK.

Anonymous, 2015. Final report ESMA guidelines on alternative performance measures. European Securities and Markets Authority, Paris, France.https://www. esma.europa.eu/sites/default/files/library/2015/11/20 15-esma-1057_final_report_on_guidelines_on_altern ative performance_measures.pdf

Arellano, M. and O. Bover, 1995. Another look at the instrumental variable estimation of error-components models. J. Econ., 68: 29-51.

Arellano, M. and S. Bond, 1991. Some tests of specification for panel data: Monte carlo evidence and an application to employment equations. Rev. Econ. Stud., 58: 277-297. 
Banker, R.D. and L. Chen, 2006. Predicting earnings using a model based on cost variability and cost stickiness. Account. Rev., 81: 285-307.

Barton, J., T.B. Hansen and G. Pownall, 2010. Which performance measures do investors around the world value the most and why?. Accounting Rev., 85: 753-789.

Blundell, R. and S. Bond, 1998. Initial conditions and moment restrictions in dynamic panel data models. J. Econ., 87: 115-143.

Brouwer, A., A. Faramarzi and M. Hoogendoorn, 2014. Does the new conceptual framework provide adequate concepts for reporting relevant information about performance?. Accounting Eur., 11: 235-257.

Cascino, S., M. Clatworthy, B.G. Osma, J. Gassen and S. Imam et al., 2016. Professional investors and the decision usefulness of financial reporting. ICAS., Edinburgh, Scotland, UK. https://www.icas.com/_data/assets/pdf_file/0010/23 6764/Professional-investors-and-the-decision-usefuln ess-of-financial-reporting.pdf

Chandra, U. and B.T. Ro, 2008. The role of revenue in firm valuation. Accounting Horiz., 22: 199-222.

Chen, S. and Y. Wang, 2004. Evidence from China on the value relevance of operating income vs. Below-the-line items. Intl. J. Accounting, 39: 339-364.

Devalle, A. and R. Magarini, 2012. Assessing the value relevance of total comprehensive income under IFRS: An empirical evidence from European stock exchanges. Intl. J. Accounting Auditing Perform. Eval., 8: 43-68.

Devalle, A., D. Busso and F. Rizzato, 2015. [What is the most significant economic performance magnitude? An empirical analysis in Italy (In Italian)]. Impresa Progetto, 3: 1-26.

Devalle, A., E. Onali and R. Magarini, 2010. Assessing the value relevance of accounting data after the introduction of IFRS in Europe. J. Int. Financial Manage. Accounting, 21: 85-119.

Ertimur, Y., J. Livnat and M. Martikainen, 2003. Differential market reactions to revenue and expense surprises. Rev. Accounting Stud., 8: 185-211.

Fair-Field, P.M., R.J. Sweeney and T.L. Yohn, 1996. Accounting classification and the predictive content of earnings. Account. Rev., 71: 337-355.

Frank, K., 2002. The effect of growth on the value relevance of accounting data. J. Bus. Res., 55: 69-78.

Hellstrom, K., 2006. The value relevance of financial accounting information in a transition economy: The case of the Czech Republic. Eur. Acc. Rev., 15: 325-349.
Holthausen, R.W. and R.L. Watts, 2001. The relevance of the value-relevance literature for financial accounting standard setting. J. Accounting Econ., 31: 3-75.

Jegadeesh, N. and J. Livnat, 2006. Revenue surprises and stock returns. Accounting Econ., 41: 147-171.

Jennings, R., M. LeClere and R.B. Thompson, 2001. Goodwill amortization and the usefulness of earnings. Financial Analysts J., 57: 20-28.

Kim, M.M., 2011. A literature review on the value relevance of geographic segment earnings. Intl. Bus. Manage., 5: 194-199.

Kim, O., 2013. Russian accounting system: Value relevance of reported information and the IFRS adoption perspective. Intl. J. Accounting, 48: 525-547.

King, R.D. and J.C. Langli, 1998. Accounting diversity and firm valuation. J. Int. Accounting, 33: 529-567.

Meulen, V.D.S., A. Gaeremynck and M. Willekens, 2007. Attribute differences between US GAAP and IFRS earnings: An exploratory study. Intl. J. Accounting, 42: 123-142.

Ohlson, J.A. and S.H. Penman, 1992. Disaggregated accounting data as explanatory variables for returns. J. Accounting Auditing Finance, 7: 553-573.

Ohlson, J.A., 1995. Earnings, book values and dividends in equity valuation. Contemp. Account. Res., 11: 661-687.

Ota, K., 2003. The impact of price and return models on value relevance studies: A review of theory and evidence. Accounting Res. J., 16: 6-20.

Qu, X. and G. Zhang, 2015. Value-relevance of earnings and book value over the institutional transition in China: The suitability of fair value accounting in this emerging market. Intl. J. Accounting, 50: 195-223.

Sami, H. and H. Zhou, 2004. A comparison of value relevance of accounting information in different segments of the Chinese Stock Market. Intl. J. Accounting, 39: 403-427.

Sami, H., 2015. Discussion of Value-relevance of earnings and book value over the institutional transition in China: The suitability of fair value accounting in this merging market. Intl. J. Accounting, 2: 224-228.

Stock, J.H. and M.W. Watson, 2003. Introduction to Econometrics. Addison Wesley, Boston, Massachusetts, ISBN:9780321223517, Pages: 696.

Sun, Y. and N. Sari, 2016. Value relevance of accounting information: Evidence from Indonesia. Soc. Sci., 11: $7568-7573$

Veith, S. and J.R. Werner, 2014. Comparative value relevance studies: Country differences versus specification effects. Intl. J. Accounting, 49: 301-330. 